\title{
Solid-Liquid Equilibria for Hexafluorophosphate-Based Ionic Liquid Quaternary Mixtures and Their Corresponding Subsystems
}

\author{
Meysam Mirarabrazi, ${ }^{\dagger}$ Mónia A. R. Martins, $^{\ddagger}, \|_{\odot \odot}$ Simão P. Pinho, ${ }^{\S} \|_{\odot}$ João A. P. Coutinho, ${ }^{\ddagger}$ \\ and Christian Robelin* ${ }^{\dagger} \uparrow$ \\ ${ }^{\dagger}$ Centre for Research in Computational Thermochemistry (CRCT), Department of Chemical Engineering, Polytechnique Montréal, \\ C.P. 6079, Succursale "Downtown", Montréal, Québec H3C 3A7, Canada \\ ${ }^{\ddagger}$ CICECO-Aveiro Institute of Materials, Department of Chemistry, University of Aveiro, 3810-193 Aveiro, Portugal \\ ${ }^{\S}$ Associate Laboratory LSRE-LCM, Department of Chemical and Biological Technology, Polytechnic Institute of Bragança, \\ 5300-253 Bragança, Portugal \\ "Mountain Research Center-CIMO, Polytechnic Institute of Bragança, 5301-855 Bragança, Portugal
}

Supporting Information

\begin{abstract}
The present work describes an experimental study and the thermodynamic modeling for the solid-liquid phase diagram of an ionic liquid quaternary system constituted by hexafluorophosphate $\left(\left[\mathrm{PF}_{6}\right]^{-}\right)$as the common anion and by 1-methyl-3-propylimidazolium $\left(\left[\mathrm{C}_{3} \mathrm{mim}\right]^{+}\right)$, 1-methyl-1-propylpyrrolidinium $\left(\left[\mathrm{C}_{3} \mathrm{mpyrr}\right]^{+}\right)$, 1-methyl-3-propylpyridinium $\left(\left[\mathrm{C}_{3} \mathrm{mpy}\right]^{+}\right)$, or 1-methyl1-propylpiperidinium $\left(\left[\mathrm{C}_{3} \mathrm{mpip}\right]^{+}\right)$as the cations. The Modified Quasichemical Model was used to model the liquid solution, and the Compound Energy Formalism was used for the relevant solid solutions. The liquidus projections of the four ternary subsystems (1) $\left[\mathrm{C}_{3} \mathrm{mim}\right]\left[\mathrm{PF}_{6}\right]-\left[\mathrm{C}_{3} \mathrm{mpip}\right]\left[\mathrm{PF}_{6}\right]-\left[\mathrm{C}_{3} \mathrm{mpyrr}\right]$ $\left[\mathrm{PF}_{6}\right],(2) \quad\left[\mathrm{C}_{3} \mathrm{mpy}\right]\left[\mathrm{PF}_{6}\right]-\left[\mathrm{C}_{3} \mathrm{mpip}\right]\left[\mathrm{PF}_{6}\right]-\left[\mathrm{C}_{3} \mathrm{mpyrr}\right]\left[\mathrm{PF}_{6}\right],(3)\left[\mathrm{C}_{3} \mathrm{mpip}\right]-$ $\left[\mathrm{PF}_{6}\right]-\left[\mathrm{C}_{3} \mathrm{mpy}\right]\left[\mathrm{PF}_{6}\right]-\left[\mathrm{C}_{3} \mathrm{mim}\right]\left[\mathrm{PF}_{6}\right]$, and (4) $\left[\mathrm{C}_{3} \mathrm{mpyrr}\right]\left[\mathrm{PF}_{6}\right]-\left[\mathrm{C}_{3} \mathrm{mpy}\right]-$ $\left[\mathrm{PF}_{6}\right]-\left[\mathrm{C}_{3} \mathrm{mim}\right]\left[\mathrm{PF}_{6}\right]$ were predicted using a standard symmetric (for systems 3 and 4) or asymmetric (for systems 1 and 2) interpolation method. In order to test

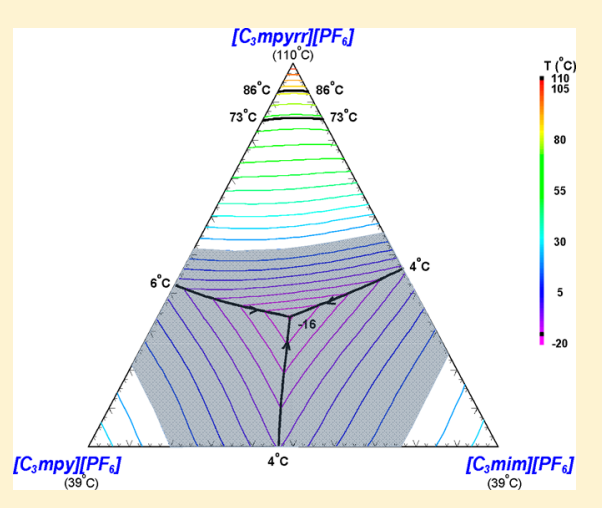
the accuracy of the thermodynamic model, two isoplethal sections were experimentally measured in each of the four ternary systems using differential scanning calorimetry. Overall, agreement was very satisfactory, not requiring fitting of any ternary interaction parameters for the liquid solution model. In each of the four calculated ternary liquidus projections, the region of composition corresponding to room temperature ionic liquid mixtures was determined. The global minimum of the liquidus temperature in the complete composition space was calculated to be about $-16^{\circ} \mathrm{C}$, with a mole percentage composition of (33.8\% $\left.\left[\mathrm{C}_{3} \mathrm{mpyrr}\right]\left[\mathrm{PF}_{6}\right]+33.9 \%\left[\mathrm{C}_{3} \mathrm{mpy}\right]\left[\mathrm{PF}_{6}\right]+32.3 \%\left[\mathrm{C}_{3} \mathrm{mim}\right]\left[\mathrm{PF}_{6}\right]\right)$.
\end{abstract}

\section{INTRODUCTION}

Ionic liquids (ILs) are, by definition, salts with a melting point below an arbitrary temperature of $100{ }^{\circ} \mathrm{C}$. Whereas many inorganic salts are symmetric in shape, ionic liquids possess a remarkably lower symmetry owing to their organic cation. Also, the latter is often aromatic, which induces a delocalization of the positive charge. For all these reasons, the melting point of ionic liquids occurs at much lower temperatures than for most inorganic salts. These ionic compounds have also been designated as "designer solvents" due to the possibility of changing a wide range of potential cation and anion combinations in order to fine-tune their physicochemical properties. $^{2}$ Owing to their distinctive characteristics including very low vapor pressure, and high chemical and thermal stability over a broad temperature range ( -40 to $\left.200{ }^{\circ} \mathrm{C}\right),^{3}$ they have found many potential applications in various fields such as analytics, ${ }^{4}$ chemical processing, ${ }^{5}$ solvents and catalysts, ${ }^{6}$ electrochemistry, ${ }^{7}$ and biomass processing ${ }^{8}$ among others. In particular, the hexafluorophosphate-based ILs investigated in this work have been used in the preparation of dye-sensitized solar cells with improved durability, ${ }^{9}$ in microfabricated liquid junction reference electrodes, ${ }^{10}$ as electrolytes of electrochemical capacitors, $^{11}$ and as a component of lithium-ion batteries. ${ }^{12}$ As reported by Stark and Seddon, ${ }^{13}$ at a zeroth-order approximation, the physical properties of ionic liquids (such as density, viscosity, and temperature of fusion) are controlled by the cations, whereas the anions govern the chemistry and reactivity. It may thus be required to fine-tune the properties of ionic liquids to achieve a specific application. Plechkova and Seddon ${ }^{14}$ suggested that this can be achieved by mixtures of ionic liquids. In particular, common-ion ionic liquid mixtures (binary, ternary, or higher-order) may have a liquidus temperature substantially lower than the melting temperatures

Received: August 7, 2019

Revised: September 13, 2019

Published: September 16, 2019 
of the corresponding pure compounds. A knowledge of the solid-liquid phase equilibria for such systems is thus of great importance. For instance, the $\mathrm{CH}_{3} \mathrm{COOLi}, \mathrm{CH}_{3} \mathrm{COOK}$, and $\mathrm{CH}_{3} \mathrm{COOCs}$ compounds have relatively high temperatures of fusion (between 190 and $306{ }^{\circ} \mathrm{C}$ ) and in principle should not be regarded as ionic liquids. However, the corresponding ternary system is predicted to display a ternary eutectic at about $95{ }^{\circ} \mathrm{C} . .^{15}$ Although ionic liquid mixtures have received much attention in recent years, ${ }^{2,16}$ a review of the literature ${ }^{17}$ showed that there are few publications dealing with phase diagram measurements. The investigated ionic liquid systems with organic cations are mainly binary systems (commonanion $^{18-26}$ or common-cation ${ }^{18,21,23,25,27-29}$ ) and ternary reciprocal $^{25,29,30}$ systems (with two cations and two anions). Attention has also been paid to common-anion binary ${ }^{31,32}$ and ternary $^{32-34}$ systems of salts with ions commonly used for the preparation of ionic liquids.

Very little effort has been also made to model the solidliquid phase diagrams of ionic liquid systems. For instance, using the Schröder-Van Laar equation, Maximo et al. ${ }^{26}$ modeled the phase diagrams of nine $\left[\mathrm{PF}_{6}\right]$-based binary ionic liquid systems with imidazolium $\left(\left[\mathrm{C}_{3} \mathrm{mim}\right]^{+}\right.$or $\left.\left[\mathrm{C}_{12} \mathrm{mim}\right]^{+}\right)$, pyrrolidinium $\left(\left[\mathrm{C}_{3} \mathrm{mpyrr}\right]^{+}\right)$, pyridinium $\left(\left[\mathrm{C}_{3} \mathrm{mpy}\right]^{+}\right)$, piperidinium $\left(\left[\mathrm{C}_{3} \text { mpip }\right]^{+}\right)$, tetrabutylammonium $\left(\left[\mathrm{N}_{4444}\right]^{+}\right)$, and tetrabutylphosphonium $\left(\left[\mathrm{P}_{4444}\right]^{+}\right)$as the different cations. In a previous study, ${ }^{17}$ using a standard CALPHAD approach, a thermodynamic model was developed for a pyrrolidiniumbased common-cation ternary ionic liquid system, and for a pyridinium-based ternary reciprocal ionic liquid system. The Modified Quasichemical Model ${ }^{35,36}$ was used to model the liquid solution, and the Compound Energy Formalism ${ }^{37,38}$ was used to model the relevant solid solutions.

In 1970, CALPHAD (CALculation of PHAse Diagrams) was introduced by Kaufman and Bernstein ${ }^{39}$ as the most efficient method of developing thermodynamic databases and calculating phase diagrams of complex systems. This method enables prediction of the phase diagrams of higher-order systems from the model parameters for their lower-order binary and ternary subsystems. ${ }^{40}$ It is based on the minimization of the Gibbs energy of the system. As a first step, the Gibbs energy of the pure components is modeled, on the basis of the available thermodynamic properties (enthalpy of formation, heat capacity, etc.); it is usually expressed as a polynomial function of temperature. Then, for every binary subsystem, all available experimental data (phase diagram, enthalpy of mixing of the liquid, activities, etc.) are collected from the literature and critically evaluated in order to obtain a set of model parameters for all phases involved. The thermodynamic properties of any ternary subsystem can be estimated from the optimized model parameters of the corresponding binary subsystems using standard interpolation methods. To obtain a quantitative description of the available experimental ternary data, ternary interaction parameters describing the mutual interaction between all three components of the system may be included in the model. Such parameters do not have any impact on the Gibbs energies of the binary subsystems. All model parameters are stored in a thermodynamic database. The models can then be used along with Gibbs energy minimization software to predict the thermodynamic properties of higher-order systems, using only the estimated parameters from the lower-order subsystems with experimental data available. ${ }^{41}$
The present article describes a thermodynamic model for the common-anion quaternary system $\left[\mathrm{C}_{3} \mathrm{mim}\right]\left[\mathrm{PF}_{6}\right]-$ $\left[\mathrm{C}_{3} \mathrm{mpy}\right]\left[\mathrm{PF}_{6}\right]-\left[\mathrm{C}_{3} \mathrm{mpyrr}\right]\left[\mathrm{PF}_{6}\right]-\left[\mathrm{C}_{3} \mathrm{mpip}\right]\left[\mathrm{PF}_{6}\right]$ (where $\mathrm{C}_{3}$ refers to a propyl group) based on SLE data. The same methodology applied before by $\mathrm{us}^{17}$ was used: as a first step, the phase diagrams of the six binary subsystems $\left(\left[\mathrm{C}_{3} \mathrm{mim}\right]\right.$ $\left[\mathrm{PF}_{6}\right]-\left[\mathrm{C}_{3} \mathrm{mpy}\right]\left[\mathrm{PF}_{6}\right], \quad\left[\mathrm{C}_{3} \mathrm{mim}\right]\left[\mathrm{PF}_{6}\right]-\left[\mathrm{C}_{3} \mathrm{mpyrr}\right]\left[\mathrm{PF}_{6}\right]$, $\left[\mathrm{C}_{3} \mathrm{mim}\right]\left[\mathrm{PF}_{6}\right]-\left[\mathrm{C}_{3} \mathrm{mpip}\right]\left[\mathrm{PF}_{6}\right], \quad\left[\mathrm{C}_{3} \mathrm{mpy}\right]\left[\mathrm{PF}_{6}\right]-\left[\mathrm{C}_{3} \mathrm{mpyrr}\right]-$ $\left[\mathrm{PF}_{6}\right], \quad\left[\mathrm{C}_{3} \mathrm{mpy}\right]\left[\mathrm{PF}_{6}\right]-\left[\mathrm{C}_{3} \mathrm{mpip}\right]\left[\mathrm{PF}_{6}\right]$, and $\left[\mathrm{C}_{3} \mathrm{mpyrr}\right]-$ $\left[\mathrm{PF}_{6}\right]-\left[\mathrm{C}_{3} \mathrm{mpip}\right]\left[\mathrm{PF}_{6}\right]$ ) were modeled on the basis of the measurements of Maximo et al., ${ }^{26}$ obtained by optical microscopy. Then, the liquidus projections of the four ternary subsystems $\left\{(1)\left[\mathrm{C}_{3} \mathrm{mim}\right]\left[\mathrm{PF}_{6}\right]-\left[\mathrm{C}_{3} \mathrm{mpip}\right]\left[\mathrm{PF}_{6}\right]-\left[\mathrm{C}_{3} \mathrm{mpyrr}\right]-\right.$ $\left[\mathrm{PF}_{6}\right],(2)\left[\mathrm{C}_{3} \mathrm{mpy}\right]\left[\mathrm{PF}_{6}\right]-\left[\mathrm{C}_{3} \mathrm{mpip}\right]\left[\mathrm{PF}_{6}\right]-\left[\mathrm{C}_{3} \mathrm{mpyrr}\right]\left[\mathrm{PF}_{6}\right]$, (3) $\left[\mathrm{C}_{3} \mathrm{mpip}\right]\left[\mathrm{PF}_{6}\right]-\left[\mathrm{C}_{3} \mathrm{mpy}\right]\left[\mathrm{PF}_{6}\right]-\left[\mathrm{C}_{3} \mathrm{mim}\right]\left[\mathrm{PF}_{6}\right]$, and (4) $\left.\left[\mathrm{C}_{3} \mathrm{mpyrr}\right]\left[\mathrm{PF}_{6}\right]-\left[\mathrm{C}_{3} \mathrm{mpy}\right]\left[\mathrm{PF}_{6}\right]-\left[\mathrm{C}_{3} \mathrm{mim}\right]\left[\mathrm{PF}_{6}\right]\right\}$ were predicted from the optimized binary parameters along with a standard symmetric (Kohler-like) ${ }^{42}$ or asymmetric (KohlerToop-like $)^{43}$ interpolation method. In order to test the accuracy of this approach, in this work two isoplethal sections were experimentally measured for each of the ternary systems using differential scanning calorimetry (DSC), with most of the measurements performed for systems 1 and 3 . The thermodynamic model parameters were slightly refitted, and in each of the four calculated ternary liquidus projections, the composition region corresponding to room temperature ionic liquid (RTIL) mixtures was determined. Finally, the composition in the quaternary system corresponding to a global minimum of the liquidus temperature was found using the program FactOptimal, ${ }^{44}$ which is a coupling of the FactSage thermochemical software ${ }^{45}$ with the powerful Mesh Adaptive Direct Search (MADS) algorithm.

\section{MATERIALS AND METHODS}

The $\left[\mathrm{C}_{3} \mathrm{mim}\right]\left[\mathrm{PF}_{6}\right], \quad\left[\mathrm{C}_{3} \mathrm{mpy}\right]\left[\mathrm{PF}_{6}\right], \quad\left[\mathrm{C}_{3} \mathrm{mpyrr}\right]\left[\mathrm{PF}_{6}\right]$, and $\left[\mathrm{C}_{3} \mathrm{mpip}\right]\left[\mathrm{PF}_{6}\right]$ pure compounds were purchased from Iolitec with a mass purity of $99 \%$. The compounds were dried under vacuum at room temperature for at least 3 days, and the purity of each sample was additionally confirmed by ${ }^{1} \mathrm{H},{ }^{13} \mathrm{C},{ }^{19} \mathrm{~F}$, and ${ }^{31} \mathrm{P}$ NMR spectra. A Metrohm 831 Karl Fischer coulometer using the analyte Hydranal-Coulomat AG, from Riedel-de Haën, was used to determine the water content of the compounds, which was found to be less than $900 \mathrm{ppm}$. Ternary mixtures were prepared inside a dry argon glovebox, at room temperature using an analytical balance model ALS 220$4 \mathrm{~N}$ from Kern with an accuracy of $\pm 0.002 \mathrm{~g}$. Vials with mixtures were heated under stirring until complete melting and then recrystallized at room temperature. Samples $(2-5 \mathrm{mg})$ of mixtures of pure compounds were hermetically sealed in aluminum pans inside the glovebox and then weighed in a microanalytical balance AD6 (PerkinElmer, USA, precision $=2$ $\times 10^{-6} \mathrm{~g}$ ). The melting properties were determined using a Hitachi DSC7000X model working at atmospheric pressure. For most DSC measurements, one cooling run at $5{ }^{\circ} \mathrm{C} \mathrm{min}{ }^{-1}$ followed by one heating run at $2{ }^{\circ} \mathrm{C} \mathrm{min}{ }^{-1}$ were performed (in particular, the minimum temperature reached upon cooling was $-100{ }^{\circ} \mathrm{C}$ for the $\left\{\left[\mathrm{C}_{3} \mathrm{mim}\right],\left[\mathrm{C}_{3} \mathrm{mpip}\right],\left[\mathrm{C}_{3} \mathrm{mpyrr}\right]\right\}\left[\mathrm{PF}_{6}\right]$ ternary system and $-180{ }^{\circ} \mathrm{C}$ for the $\left\{\left[\mathrm{C}_{3} \mathrm{mim}\right],\left[\mathrm{C}_{3} \mathrm{mpip}\right]\right.$, $\left.\left[\mathrm{C}_{3} \mathrm{mpy}\right]\right\}\left[\mathrm{PF}_{6}\right]$ ternary system $)$, and only the thermal transitions of the heating run were taken into account. For a few ternary mixtures, three consecutive heating/cooling cycles were used with rates of $2{ }^{\circ} \mathrm{C} \mathrm{min}{ }^{-1}$ (heating) and $5{ }^{\circ} \mathrm{C} \mathrm{min}{ }^{-1}$ (cooling), respectively. Only the thermal transitions of the last 

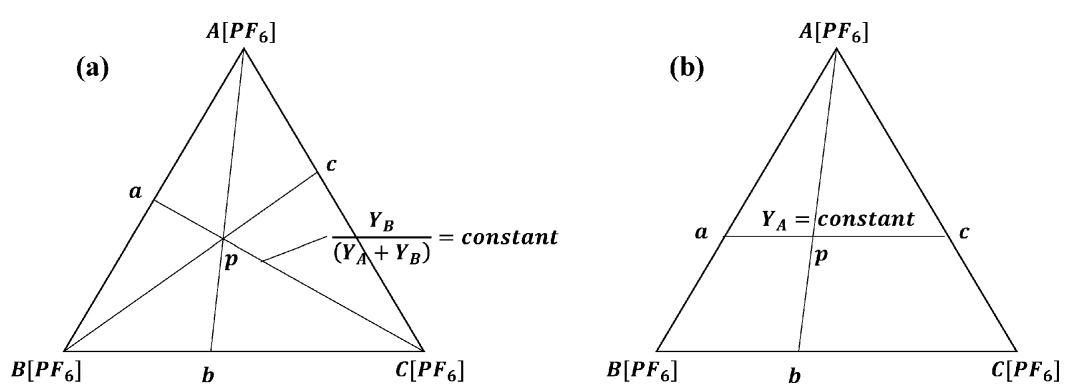

Figure 1. Symmetric (a) and asymmetric (b) models for interpolation from binary to ternary liquid solutions.

two heating runs were then considered. The use of this latter DSC protocol will be clearly stated in the text. The equipment was previously calibrated with several standards with mass percentage purities higher than $99 \%$. The melting temperatures reported were taken as the peak temperatures for the endothermic changes in heat flows. Uncertainties of $1{ }^{\circ} \mathrm{C}$ in the melting temperatures are estimated, on the basis of the average standard deviation of measurements for the ternary mixtures studied more than once.

\section{THERMODYNAMIC MODELING}

3.1. Liquid Phase. In this work, the Modified Quasichemical Model in the Pair Approximation (MQMPA) ${ }^{35,36}$ was used for the liquid phase. This model considers the distribution of cations and anions on the sites of two different sublattices (cationic and anionic), and each ion occupies exactly one site. Let us consider first the $\mathrm{A}\left[\mathrm{PF}_{6}\right]-\mathrm{B}\left[\mathrm{PF}_{6}\right]$ common-anion binary system (abbreviated as $\mathrm{A}, \mathrm{B} /\left[\mathrm{PF}_{6}\right]$ ), where $\mathrm{A}$ and $\mathrm{B}$ are two different cations $\left(\left[\mathrm{C}_{3} \mathrm{mim}\right]^{+},\left[\mathrm{C}_{3} \mathrm{mpy}\right]^{+},\left[\mathrm{C}_{3} \mathrm{mpyrr}\right]^{+}\right.$, or $\left[\mathrm{C}_{3} \mathrm{mpip}\right]^{+}$in the present case), and $\left[\mathrm{PF}_{6}\right]^{-}$is the common anion. In such conditions, the MQMPA takes into account short-range ordering (SRO) between second-nearest-neighbor (SNN) cation-cation pairs. The following pair-exchange reaction is considered:

$$
\begin{aligned}
& \left(\mathrm{A}-\left[\mathrm{PF}_{6}\right]-\mathrm{A}\right)_{\text {pair }}+\left(\mathrm{B}-\left[\mathrm{PF}_{6}\right]-\mathrm{B}\right)_{\text {pair }}=2\left(\mathrm{~A}-\left[\mathrm{PF}_{6}\right]-\mathrm{B}\right)_{\text {pair }} \\
& \Delta g_{\mathrm{AB} /\left[\mathrm{PF}_{6}\right]}
\end{aligned}
$$

where $\Delta g_{\mathrm{AB} /\left[\mathrm{PF}_{6}\right]}$ is the Gibbs energy change for the formation of 2 mol of the $\left(\mathrm{A}-\left[\mathrm{PF}_{6}\right]-\mathrm{B}\right)$ pair. This is a model parameter, which is expanded in terms of the pair fractions as

$$
\Delta g_{\mathrm{AB} /\left[\mathrm{PF}_{6}\right]}=\Delta g_{\mathrm{AB} /[\mathrm{PF}]}^{0}+\sum_{i \geq 1} g_{\mathrm{AB} /\left[\mathrm{PF}_{6}\right]}^{i 0} x_{\mathrm{AA}}^{i}+\sum_{j \geq 1} g_{\mathrm{AB} /\left[\mathrm{PF}{ }_{6}\right]}^{0 j} x_{\mathrm{BB}}^{j}
$$

where $\Delta g_{\mathrm{AB} /\left[\mathrm{PF}_{6}\right]}^{0}, g_{\mathrm{AB} /\left[\mathrm{PF}_{6}\right]}^{i 0}, \quad$ and $g_{\mathrm{AB} /\left[\mathrm{PF}_{6}\right]}^{0 j}$ are empirical coefficients that can be temperature dependent, and $x_{\mathrm{AA}}$ (or $\left.x_{\mathrm{BB}}\right)$ is the mole fraction of $\left(\mathrm{A}-\left[\mathrm{PF}_{6}\right]-\mathrm{A}\right)$ (or $\mathrm{B}-\left[\mathrm{PF}_{6}\right]-\mathrm{B}$ ) SNN pairs. As $\Delta g_{\mathrm{AB} /\left[\mathrm{PF}_{6}\right]}$ becomes progressively more negative, reaction 1 is shifted to the right, $\left(\mathrm{A}-\left[\mathrm{PF}_{6}\right]-\mathrm{B}\right)$ pairs predominate, and second-nearest-neighbor cation-cation short-range ordering results. Let us now consider the $\mathrm{A}\left[\mathrm{PF}_{6}\right]-\mathrm{B}\left[\mathrm{PF}_{6}\right]-\mathrm{C}\left[\mathrm{PF}_{6}\right]$ common-anion ternary system (abbreviated as $A, B, C /\left[\mathrm{PF}_{6}\right]$ ), where $A, B$, and $C$ are three cations, and $\left[\mathrm{PF}_{6}\right]^{-}$is the common anion. The Gibbs energy of the $\mathrm{A}, \mathrm{B}, \mathrm{C} /\left[\mathrm{PF}_{6}\right]$ common-anion ternary liquid is given by

$$
\begin{aligned}
G= & \left(n_{\mathrm{A} /\left[\mathrm{PF}_{6}\right.} g_{\mathrm{A} /\left[\mathrm{PF}_{6}\right]}^{0}+n_{\mathrm{B} /\left[\mathrm{PF}_{6}\right.} g_{\mathrm{B} /\left[\mathrm{PF}_{6}\right]}^{0}+n_{\mathrm{C} /\left[\mathrm{PF}_{6}\right]} g_{\mathrm{C} /\left[\mathrm{PF}_{6}\right]}^{0}\right) \\
& -T \Delta S^{\text {config }}+\left[\left(\frac{n_{\mathrm{AB}}}{2}\right) \Delta g_{\mathrm{AB} /\left[\mathrm{PF}_{6}\right]}+\left(\frac{n_{\mathrm{AC}}}{2}\right) \Delta g_{\mathrm{AC} /\left[\mathrm{PF}_{6}\right]}\right. \\
& \left.+\left(\frac{n_{\mathrm{BC}}}{2}\right) \Delta g_{\mathrm{BC} /\left[\mathrm{PF}_{6}\right]}\right]
\end{aligned}
$$

where $n_{\mathrm{A} /\left[\mathrm{PF}_{6}\right]}, n_{\mathrm{B} /\left[\mathrm{PF}_{6}\right]}$, and $n_{\mathrm{C} /\left[\mathrm{PF}_{6}\right]}$ as well as $g_{\mathrm{A} /\left[\mathrm{PF}_{6}\right]}^{0}, g_{\mathrm{B} /\left[\mathrm{PF}_{6}\right]}^{0}$, and $g_{\mathrm{C} /\left[\mathrm{PF}_{6}\right]}^{0}$ are the number of moles and the molar Gibbs energies of the $\mathrm{A}\left[\mathrm{PF}_{6}\right], \mathrm{B}\left[\mathrm{PF}_{6}\right]$, and $\mathrm{C}\left[\mathrm{PF}_{6}\right]$ pure components, respectively; $n_{\mathrm{AB}}, n_{\mathrm{AC}}$, and $n_{\mathrm{BC}}$ are the number of moles of (A$\left.\left[\mathrm{PF}_{6}\right]-\mathrm{B}\right),\left(\mathrm{A}-\left[\mathrm{PF}_{6}\right]-\mathrm{C}\right)$, and $\left(\mathrm{B}-\left[\mathrm{PF}_{6}\right]-\mathrm{C}\right)$ cation-cation pairs, respectively; $\Delta g_{\mathrm{AB} /\left[\mathrm{PF}_{6}\right]}, \Delta g_{\mathrm{AC} /\left[\mathrm{PF}_{6}\right]}$, and $\Delta g_{\mathrm{BC} /\left[\mathrm{PF}_{6}\right]}$ are the Gibbs energy changes for the formation of $2 \mathrm{~mol}$ of (A$\left.\left[\mathrm{PF}_{6}\right]-\mathrm{B}\right),\left(\mathrm{A}-\left[\mathrm{PF}_{6}\right]-\mathrm{C}\right)$, and $\left(\mathrm{B}-\left[\mathrm{PF}_{6}\right]-\mathrm{C}\right)$ pairs, respectively; and $\Delta S^{\text {config }}$ is an approximate expression of the configurational entropy of mixing given by randomly distributing the SNN cation-cation pairs.

$$
\begin{aligned}
\Delta S^{\text {config }}= & -R\left(n_{\mathrm{A}} \ln x_{\mathrm{A}}+n_{\mathrm{B}} \ln x_{\mathrm{B}}+n_{\mathrm{C}} \ln x_{\mathrm{C}}\right) \\
& -R\left[n_{\mathrm{AA}} \ln \left(\frac{x_{\mathrm{AA}}}{Y_{\mathrm{A}}^{2}}\right)+n_{\mathrm{BB}} \ln \left(\frac{x_{\mathrm{BB}}}{Y_{\mathrm{B}}^{2}}\right)\right. \\
& +n_{\mathrm{CC}} \ln \left(\frac{x_{\mathrm{CC}}}{Y_{\mathrm{C}}^{2}}\right)+n_{\mathrm{AB}} \ln \left(\frac{x_{\mathrm{AB}}}{2 Y_{\mathrm{A}} Y_{\mathrm{B}}}\right) \\
& \left.+n_{\mathrm{AC}} \ln \left(\frac{x_{\mathrm{AC}}}{2 Y_{\mathrm{A}} Y_{\mathrm{C}}}\right)+n_{\mathrm{BC}} \ln \left(\frac{x_{\mathrm{BC}}}{2 Y_{\mathrm{B}} Y_{\mathrm{C}}}\right)\right]
\end{aligned}
$$

In eq $4, x_{A}, x_{B}$, and $x_{C}$ are the overall cationic site fractions; $Y_{A}$ $Y_{\mathrm{B}}$, and $Y_{\mathrm{C}}$ are the "coordination-equivalent" fractions; and $x_{\mathrm{AA}}$ $x_{\mathrm{BB}}, x_{\mathrm{CC}}, x_{\mathrm{AB}}, x_{\mathrm{AC}}$, and $x_{\mathrm{BC}}$ are the SNN cation-cation pair fractions according to

$$
\begin{aligned}
& x_{i}=\frac{n_{i}}{\left(n_{\mathrm{A}}+n_{\mathrm{B}}+n_{\mathrm{C}}\right)} \\
& x_{\mathrm{AB}}=\frac{n_{\mathrm{AB}}}{\left(n_{\mathrm{AA}}+n_{\mathrm{BB}}+n_{\mathrm{CC}}+n_{\mathrm{AB}}+n_{\mathrm{AC}}+n_{\mathrm{BC}}\right)} \\
& Y_{i}=\frac{Z_{i} x_{i}}{\left(Z_{\mathrm{A}} x_{\mathrm{A}}+Z_{\mathrm{B}} x_{\mathrm{B}}+Z_{\mathrm{C}} x_{\mathrm{C}}\right)}
\end{aligned}
$$

where $i=\mathrm{A}, \mathrm{B}, \mathrm{C}$, and $Z_{i}$ is the SNN coordination number of cation $i$. $Z_{i}$ should be regarded as a model parameter which may differ from the actual physical coordination number. In the present work, all SNN coordination numbers were set to 6.0. The same approach has been used successfully to model several common-anion binary inorganic liquids ${ }^{46-48}$ such as 
$\mathrm{NaCl}-\mathrm{KCl}, \mathrm{NaF}-\mathrm{KF}$, and $\mathrm{MgCl}_{2}-\mathrm{FeCl}_{2}$, which display small deviations from ideality. As will be shown later, the ionic liquid binary mixtures investigated in this work are close to ideal. Owing to all SNN coordination numbers being equal, $Y_{\mathrm{A}}, Y_{\mathrm{B}}$, and $Y_{\mathrm{C}}$ reduce to the mole fractions $x_{\mathrm{A}}, x_{\mathrm{B}}$, and $x_{\mathrm{C}}$, respectively. For a liquid solution close to ideality, it can be shown that $x_{i i}$ $\rightarrow Y_{i}^{2}$ and $x_{i j} \rightarrow 2 Y_{i} Y_{j}$ (where $i, j=\mathrm{A}, \mathrm{B}, \mathrm{C}$ ). The second term in eq 4 is then equal to zero, and the configurational entropy thus reduces to the Bragg-Williams (random-mixing) expression. For further details, one is referred to the work of Pelton and collaborators. ${ }^{35,36}$

The Gibbs energy of the common-anion ternary liquid is estimated from the optimized binary parameters using a Kohler-like (i.e., symmetric model $)^{42}$ or a Kohler-Toop-like (i.e., asymmetric model) interpolation method. ${ }^{43}$

In a symmetric model like that presented in Figure 1a, the three components are treated in the same way. $\Delta g_{\mathrm{AB} /\left[\mathrm{PF}_{6}\right]}$ in the common-anion ternary liquid is given by

$$
\begin{aligned}
\Delta g_{\mathrm{AB} /[\mathrm{PF} 6]}= & \Delta g_{\mathrm{AB} /\left[\mathrm{PF}_{6}\right]}^{0} \\
& +\sum_{(i+j) \geq 1} g_{\mathrm{AB} /\left[\mathrm{PF}_{6} 6\right.}^{i j}\left(\frac{x_{\mathrm{AA}}}{x_{\mathrm{AA}}+x_{\mathrm{AB}}+x_{\mathrm{BB}}}\right)^{i}\left(\frac{x_{\mathrm{BB}}}{x_{\mathrm{AA}}+x_{\mathrm{AB}}+x_{\mathrm{BB}}}\right)^{j} \\
& +\sum_{\substack{k \geq 1 \\
i \geq 0 \\
j \geq 0}} g_{\mathrm{AB}(\mathrm{C}) /\left[\mathrm{PF}_{6}\right]}^{i k}\left(\frac{x_{\mathrm{AA}}}{x_{\mathrm{AA}}+x_{\mathrm{AB}}+x_{\mathrm{BB}}}\right)\left(\frac{x_{\mathrm{BB}}}{x_{\mathrm{AA}}+x_{\mathrm{AB}}+x_{\mathrm{BB}}}\right)^{j} Y_{\mathrm{C}}^{k}
\end{aligned}
$$

where the second summation in eq 8 consists of a ternary term which is zero in the $\mathrm{A}, \mathrm{B} /\left[\mathrm{PF}_{6}\right]$ binary subsystem, and which gives the effect of the presence of component $\mathrm{C}\left[\mathrm{PF}_{6}\right]$ upon the pair formation energy $\Delta \mathrm{g}_{\mathrm{AB} /\left[\mathrm{PF}_{6}\right]}$. The empirical ternary coefficients $g_{\mathrm{AB}(\mathrm{C}) /\left[\mathrm{PF}_{6}\right]}^{\mathrm{ijk}}$ are obtained using experimental ternary data, but no ternary terms were required in the present work. As $\Delta g_{\mathrm{AB} /\left[\mathrm{PF}_{6}\right]}, \Delta g_{\mathrm{AC} /\left[\mathrm{PF}_{6}\right]}$, and $\Delta g_{\mathrm{BC} /\left[\mathrm{PF}_{6}\right]}$ become small, the solution approaches ideality, and $x_{\mathrm{AA}} \rightarrow Y_{\mathrm{A}}^{2}, x_{\mathrm{BB}} \rightarrow Y_{\mathrm{B}}^{2}$, and $x_{\mathrm{AB}}$ $\rightarrow 2 Y_{\mathrm{A}} Y_{\mathrm{B}}$. In this case, $\left(\frac{x_{\mathrm{AA}}}{x_{\mathrm{AA}}+x_{\mathrm{AB}}+x_{\mathrm{BB}}}\right) \rightarrow\left(\frac{Y_{\mathrm{A}}}{Y_{\mathrm{A}}+Y_{\mathrm{B}}}\right)^{2}$ and $\left(\frac{x_{\mathrm{BB}}}{x_{\mathrm{AA}}+x_{\mathrm{AB}}+x_{\mathrm{BB}}}\right) \rightarrow\left(\frac{Y_{\mathrm{B}}}{Y_{\mathrm{A}}+Y_{\mathrm{B}}}\right)^{2}$. Equation 8 then approaches the Kohler equation (eq 20 in ref 36 ) for symmetric ternary systems. Let us consider any ternary composition (point $p$ in Figure 1a). The first two terms on the right-hand side of eq 8 are constant along the line $\mathrm{C}\left[\mathrm{PF}_{6}\right]-a$ and are equal to $\Delta g_{\mathrm{AB} /\left[\mathrm{PF}_{6}\right]}$ in the A,B/[$\left[\mathrm{PF}_{6}\right]$ binary system at point $a$ (where $Y_{\mathrm{A}}$ $\left.+Y_{\mathrm{B}}=1\right)$. That is, it is assumed that the binary $\left(\mathrm{A}-\left[\mathrm{PF}_{6}\right]-\mathrm{B}\right)$ pair interaction energy is constant at a constant $\frac{Y_{A}}{Y_{B}}$ ratio. Expressions similar to eq 8 give $\Delta g_{\mathrm{BC} /\left[\mathrm{PF}_{6}\right]}$ and $\Delta g_{\mathrm{AC} /\left[\mathrm{PF}_{6}\right]}$, with the binary terms equal to their values at points $b$ and $c$, respectively, in Figure 1a.

In an asymmetric model like that presented in Figure $1 b$, one component $\left(\mathrm{A}\left[\mathrm{PF}_{6}\right]\right)$ is treated differently than the other two components. $\Delta g_{\mathrm{AB} /\left[\mathrm{PF}_{6}\right]}$ in the common-anion ternary liquid is given by

$$
\begin{aligned}
\Delta g_{\mathrm{AB} /\left[\mathrm{PF}_{6}\right]}= & \Delta g_{\mathrm{AB} /\left[\mathrm{PF}_{6}\right]}^{0}+\sum_{(i+j) \geq 1} g_{\mathrm{AB} /\left[\mathrm{PF}_{6}\right]}^{i j} x_{\mathrm{AA}}^{i}\left(x_{\mathrm{BB}}+x_{\mathrm{BC}}+x_{\mathrm{CC}}\right)^{j} \\
& +\sum_{\substack{k \geq 1 \\
i \geq 0}} g_{\mathrm{AB}(\mathrm{C}) /\left[\mathrm{PF}_{6}\right]_{\mathrm{AA}}^{i j k}}^{i}\left(x_{\mathrm{BB}}+x_{\mathrm{BC}}+x_{\mathrm{CC}}\right)^{j}\left(\frac{Y_{\mathrm{C}}}{Y_{\mathrm{B}}+Y_{\mathrm{C}}}\right)^{k}
\end{aligned}
$$

In the limit of ideality, $x_{\mathrm{AA}} \rightarrow Y_{\mathrm{A}}^{2}$ and $\left(x_{\mathrm{BB}}+x_{\mathrm{BC}}+x_{\mathrm{CC}}\right) \rightarrow\left(Y_{\mathrm{B}}\right.$ $\left.+Y_{\mathrm{C}}\right)^{2}=\left(1-Y_{\mathrm{A}}\right)^{2}$. Equation 9 approaches the Kohler-Toop equation (eq 21 in ref 36$)$ for asymmetric ternary systems. The first two terms on the right-hand side of eq 9 are constant along the line $a c$ in Figure $1 \mathrm{~b}$ and are equal to $\Delta g_{\mathrm{AB} /\left[\mathrm{PF}_{6}\right]}$ in the $\mathrm{A}, \mathrm{B} /\left[\mathrm{PF}_{6}\right]$ binary system at point $a$. An equation similar to eq 9 gives $\Delta g_{\mathrm{AC}^{\prime}\left[\mathrm{PF}_{6}\right]}$, while $\Delta g_{\mathrm{BC} /\left[\mathrm{PF}_{6}\right]}$ is given by a result similar to eq 8 .

As will be discussed in Section 4.3 , the $\left[\mathrm{C}_{3} \mathrm{mpip}\right]\left[\mathrm{PF}_{6}\right]-$ $\left[\mathrm{C}_{3} \mathrm{mpy}\right]\left[\mathrm{PF}_{6}\right]-\left[\mathrm{C}_{3} \mathrm{mim}\right]\left[\mathrm{PF}_{6}\right]$ and $\left[\mathrm{C}_{3} \mathrm{mpyrr}\right]\left[\mathrm{PF}_{6}\right]-$ $\left[\mathrm{C}_{3} \mathrm{mpy}\right]\left[\mathrm{PF}_{6}\right]-\left[\mathrm{C}_{3} \mathrm{mim}\right]\left[\mathrm{PF}_{6}\right]$ ternary systems are considered to be "symmetric" while the $\left[\mathrm{C}_{3} \mathrm{mim}\right]\left[\mathrm{PF}_{6}\right]-\left[\mathrm{C}_{3} \mathrm{mpip}\right]\left[\mathrm{PF}_{6}\right]-$ $\left[\mathrm{C}_{3} \mathrm{mpyrr}\right]\left[\mathrm{PF}_{6}\right]$ and $\left[\mathrm{C}_{3} \mathrm{mpy}\right]\left[\mathrm{PF}_{6}\right]-\left[\mathrm{C}_{3} \mathrm{mpip}\right]\left[\mathrm{PF}_{6}\right]-$ $\left[\mathrm{C}_{3}\right.$ mpyrr $]\left[\mathrm{PF}_{6}\right]$ ternary systems are considered to be asymmetric with $\left[\mathrm{C}_{3} \mathrm{mim}\right]\left[\mathrm{PF}_{6}\right]$ (respectively, $\left[\mathrm{C}_{3} \mathrm{mpy}\right]\left[\mathrm{PF}_{6}\right]$ ) as the "asymmetric" component. The composition variables $\chi_{\mathrm{AB}}$, defined previously, ${ }^{36}$ that are relevant for the present work, are given by eqs S1-S5 in the Supporting Information.

As will be shown in Section 4.2, the optimized model parameters $\Delta g_{\mathrm{AB} /\left[\mathrm{PF}_{6}\right]}$ for the six binary subsystems of the $\left[\mathrm{C}_{3} \mathrm{mim}\right]\left[\mathrm{PF}_{6}\right]-\left[\mathrm{C}_{3} \mathrm{mpy}\right]\left[\mathrm{PF}_{6}\right]-\left[\mathrm{C}_{3} \mathrm{mpyrr}\right]\left[\mathrm{PF}_{6}\right]-\left[\mathrm{C}_{3} \mathrm{mpip}\right]-$ $\left[\mathrm{PF}_{6}\right]$ system are relatively small in amplitude. Therefore, the investigated common-anion quaternary liquid exhibits relatively little second-nearest-neighbor (cation-cation) shortrange ordering. Thus, the Bragg-Williams (random-mixing) model could have been used successfully for this liquid. This model is presented in detail in ref 49 and is briefly described in ref 50. The Modified Quasichemical Model was finally selected in the present work since it is suitable for diverse liquids (with small or extensive short-range ordering, or with positive deviations from ideality), making it possible to develop large thermodynamic databases.

3.2. Solid Phase. The solid solutions relevant for the present work are those for the binary system $\left[\mathrm{C}_{3} \mathrm{mpip}\right]\left[\mathrm{PF}_{6}\right]-$ $\left[\mathrm{C}_{3}\right.$ mpyrr $]\left[\mathrm{PF}_{6}\right]$ in the complete temperature range. They were all described using the Compound Energy Formalism. ${ }^{37,38}$ The cations $\left[\mathrm{C}_{3} \text { mpip }\right]^{+}$and $\left[\mathrm{C}_{3} \mathrm{mpyrr}\right]^{+}$reside on the cationic sublattice $\mathrm{C}$ while the anion $\left[\mathrm{PF}_{6}\right]^{-}$resides on the anionic sublattice A. The molar Gibbs energy of each solid solution is then given by the following equation:

$$
\begin{aligned}
G= & y_{\left[\mathrm{C}_{3} \mathrm{mpip}\right]^{+}}^{\mathrm{C}} G_{\left[\mathrm{C}_{3} \mathrm{mpip}\right]^{+}:\left[\mathrm{PF}_{6}\right]^{-}}^{0}+y_{\left[\mathrm{C}_{3} \mathrm{mpyrr}\right]^{+}}^{\mathrm{C}} G_{\left[\mathrm{C}_{3} \mathrm{mpyrr}^{+}:\left[\mathrm{PF}_{6}\right]^{-}\right.}^{0} \\
& +R T\left(y_{\left[\mathrm{C}_{3} \mathrm{mpip}\right]^{+}}^{\mathrm{C}} \ln y_{\left[\mathrm{C}_{3} \mathrm{mpip}\right]^{+}}^{\mathrm{C}}+y_{\left[\mathrm{C}_{3} \mathrm{mpyrr}\right]^{+}}^{\mathrm{C}} \ln y_{\left[\mathrm{C}_{3} \mathrm{mpyrr}\right]^{+}}^{\mathrm{C}}\right) \\
& +G^{\mathrm{E}}
\end{aligned}
$$

The first two terms represent the reference Gibbs energy of the solution, where $y_{\left[\mathrm{C}_{3} \mathrm{mpip}\right]^{+}}^{\mathrm{C}}$ and $y_{\left[\mathrm{C}_{3} \mathrm{mpyrr}\right]^{+}}^{\mathrm{C}}$ are the site fractions of $\left[\mathrm{C}_{3} \mathrm{mpip}\right]^{+}$and $\left[\mathrm{C}_{3} \mathrm{mpyrr}\right]^{+}$on the cationic sublattice $\mathrm{C}$, and $G_{\left[\mathrm{C}_{3} \mathrm{mpip}\right]^{+}:\left[\mathrm{PF}_{6}\right]^{-}}^{0}$ and $\mathrm{G}_{\left[\mathrm{C}_{3} \mathrm{mpyrr}^{+}:\left[\mathrm{PF}_{6}\right]^{-}\right.}^{0}$ are the standard molar Gibbs energies of the end-member components [ $\left.\mathrm{C}_{3} \mathrm{mpip}\right]$ $\left[\mathrm{PF}_{6}\right]\left(s_{1}, s_{2}\right.$, or $\left.s_{3}\right)$ and $\left[\mathrm{C}_{3} \mathrm{mpyrr}\right]\left[\mathrm{PF}_{6}\right]\left(s_{1}, s_{2}\right.$, or $\left.s_{3}\right)$, respectively (where $s_{1}, s_{2}$, and $s_{3}$ are the three allotropes of each compound). The third term in eq 10 gives the ideal entropy of 
mixing (Temkin type ${ }^{51}$ ), assuming a random distribution of the cations on the cationic sublattice. The final term is the molar excess Gibbs energy and is expressed as follows:

$$
G^{\mathrm{E}}=y_{\left[\mathrm{C}_{3} \mathrm{mpip}\right]^{+}}^{\mathrm{C}} y_{\left[\mathrm{C}_{3} \mathrm{mpyrr}\right]^{+}}^{\mathrm{C}} L_{\left[\mathrm{C}_{3} \mathrm{mpip}\right]^{+},\left[\mathrm{C}_{3} \mathrm{mpyrr}\right]^{+}:\left[\mathrm{PF}_{6}\right]^{-}}
$$

The $L$ factor may depend on the temperature and also on the composition, where Redlich-Kister terms as a function of site fractions are generally used.

\section{RESULTS AND DISCUSSION}

4.1. Pure Ionic Liquids. Figure 2 shows the chemical structures of the four $\left[\mathrm{PF}_{6}\right]$-based ionic liquids investigated in<smiles></smiles>

(a)

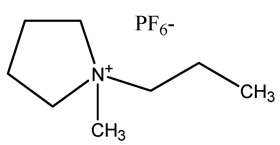

(c)<smiles>CCC[n+]1cccc(C)c1</smiles>

(b)

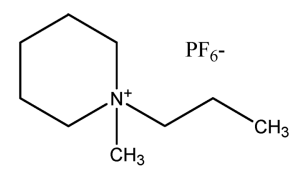

(d)
Figure 2. Chemical structures of the $\left[\mathrm{PF}_{6}\right]$-based ionic liquids: (a) $\left[\mathrm{C}_{3} \mathrm{mim}\right]\left[\mathrm{PF}_{6}\right]$, (b) $\left[\mathrm{C}_{3} \mathrm{mpy}\right]\left[\mathrm{PF}_{6}\right]$, (c) $\left[\mathrm{C}_{3} \mathrm{mpyrr}\right]\left[\mathrm{PF}_{6}\right]$, and (d) $\left[\mathrm{C}_{3} \mathrm{mpip}\right]\left[\mathrm{PF}_{6}\right]$.

the present work. Maximo et al. ${ }^{26}$ measured their thermal transitions by DSC and also measured their melting temperatures using optical microscopy. The crystal structures of the pure compounds were determined by single crystal X-ray diffraction at $180 \mathrm{~K}$. Table 1 gives the thermal transition data from Maximo et $\mathrm{al}^{26}$ along with the data collected from the literature. For the sake of consistency, the data of Maximo et al. are used directly in the present work. In particular, $\left[\mathrm{C}_{3} \mathrm{mpyrr}\right.$ $\left[\mathrm{PF}_{6}\right]$ and $\left[\mathrm{C}_{3} \mathrm{mpip}\right]\left[\mathrm{PF}_{6}\right]$ both have three allotropes $\left(s_{1}, s_{2}\right.$, $\left.s_{3}\right)$.

As mentioned previously, ${ }^{17}$ to model the phase diagram of a common-anion system such as $\left[\mathrm{C}_{3} \mathrm{mim}\right]\left[\mathrm{PF}_{6}\right]-\left[\mathrm{C}_{3} \mathrm{mpy}\right]-$ $\left[\mathrm{PF}_{6}\right]-\left[\mathrm{C}_{3} \mathrm{mpyrr}\right]\left[\mathrm{PF}_{6}\right]-\left[\mathrm{C}_{3} \mathrm{mpip}\right]\left[\mathrm{PF}_{6}\right]$ for which measurements are available, only the molar Gibbs energies of fusion and the molar Gibbs energies of solid-solid transition (if different allotropes exist) of the pure compounds need to be known. The molar Gibbs energy of fusion of the pure compound $m$ may be written as

$$
\Delta g_{\text {fusion }(m)}^{0}=\Delta h_{\text {fusion }(m)}^{0}\left(1-\frac{T}{T_{\text {fusion }(m)}}\right)
$$

where the enthalpy of fusion $\Delta h_{\text {fusion }(m)}^{0}$ is independent of the temperature to a first approximation. Similarly, the molar Gibbs energy of the solid-solid transition for a compound displaying two or more allotropes $\left(s_{1}, s_{2}, \ldots\right)$ may be written as

$$
\Delta g_{\operatorname{trans}\left(s_{i}\right)}^{0}=\Delta h_{\operatorname{trans}\left(s_{i}\right)}^{0}\left(1-\frac{T}{T_{\operatorname{trans}\left(s_{i}\right)}}\right)
$$

4.2. Binary Subsystems. The phase diagrams of the six binary subsystems have been measured by Maximo et al. ${ }^{26}$ using mainly optical microscopy. No intermediate compound has been observed. The calculated phase diagrams are discussed below.

4.2.1. Phase Diagrams with a Simple Eutectic Behavior. Figure 3 displays the calculated phase diagrams for the $\left[\mathrm{C}_{3} \mathrm{mpy}\right]\left[\mathrm{PF}_{6}\right]-\left[\mathrm{C}_{3} \mathrm{mim}\right]\left[\mathrm{PF}_{6}\right], \quad\left[\mathrm{C}_{3} \mathrm{mpip}\right]\left[\mathrm{PF}_{6}\right]-\left[\mathrm{C}_{3} \mathrm{mim}\right]-$ $\left[\mathrm{PF}_{6}\right], \quad\left[\mathrm{C}_{3} \mathrm{mpyrr}\right]\left[\mathrm{PF}_{6}\right]-\left[\mathrm{C}_{3} \mathrm{mim}\right]\left[\mathrm{PF}_{6}\right],\left[\mathrm{C}_{3} \mathrm{mpy}\right]\left[\mathrm{PF}_{6}\right]-$ $\left[\mathrm{C}_{3} \mathrm{mpyrr}\right]\left[\mathrm{PF}_{6}\right]$, and $\left[\mathrm{C}_{3} \mathrm{mpip}\right]\left[\mathrm{PF}_{6}\right]-\left[\mathrm{C}_{3} \mathrm{mpy}\right]\left[\mathrm{PF}_{6}\right]$ binary systems along with the experimental data from Maximo et al. ${ }^{26}$ These are simple eutectic systems with negligible solid solubility. The characteristics of the calculated binary eutectic (temperature and composition) are shown for each system. Agreement between the calculations and the measurements is satisfactory. Table 2 gives the optimized Gibbs energy of reaction 1 for each binary liquid. The composition variables $\chi_{\mathrm{AB}}$ used in this table are defined by eqs $\mathrm{S} 1-\mathrm{S} 5$ in the Supporting Information. These expressions are valid in the quaternary system, and for any binary system $\mathrm{A}\left[\mathrm{PF}_{6}\right]-\mathrm{B}\left[\mathrm{PF}_{6}\right]$ (where $\mathrm{A}, \mathrm{B}=\left[\mathrm{C}_{3} \mathrm{mim}\right],\left[\mathrm{C}_{3} \mathrm{mpy}\right],\left[\mathrm{C}_{3} \mathrm{mpip}\right],\left[\mathrm{C}_{3} \mathrm{mpyrr}\right]$ ), they reduce to

$$
\chi_{\mathrm{AB}}=x_{\mathrm{AA}}
$$

Once numerical values are estimated for the empirical coefficients in eq 2, the Gibbs energy of the $\mathrm{A}\left[\mathrm{PF}_{6}\right]-\mathrm{B}\left[\mathrm{PF}_{6}\right]$ binary liquid is defined, which also applies to the $\mathrm{A}\left[\mathrm{PF}_{6}\right]-$ $\mathrm{B}\left[\mathrm{PF}_{6}\right]-\mathrm{C}\left[\mathrm{PF}_{6}\right]$ ternary liquid through eqs 3 and 4 . The equilibrium cation-cation pair composition $\left(x_{\mathrm{AA}}, x_{\mathrm{BB}}\right.$, and $\left.x_{\mathrm{AB}}\right)$ is the one that minimizes the Gibbs energy of the $A\left[\mathrm{PF}_{6}\right]-$ $\mathrm{B}\left[\mathrm{PF}_{6}\right]$ binary liquid at a given temperature, pressure, and (global) composition. This permits to calculate all thermodynamic properties, including the binary phase diagram. The set of empirical coefficients in eq 2 permitting the best reproduction of all available experimental binary data (the phase diagram in the present work) was retained.

As seen in Table 2, the optimized parameters for the

\begin{tabular}{|c|c|c|c|c|c|c|}
\hline ionic liquid & $\begin{array}{l}\text { water content } \\
\quad(\text { wt } \%)\end{array}$ & purity (\%) & $\begin{array}{l}\text { melting } \\
\text { temp (K) }\end{array}$ & $\begin{array}{l}\text { enthalpy of fusion } \\
\quad\left(\mathrm{J} \mathrm{mol}^{-1}\right)\end{array}$ & solid-solid transition & ref \\
\hline \multirow[t]{2}{*}[\mathrm{C}_{3}\operatorname{mim}]{$\left[\mathrm{PF}_{6}\right]$} & $<0.5$ & $>99$ & 312 & 14260 & & 26 \\
\hline & $<20 \mathrm{ppm}$ & & 313 & & & 52 \\
\hline$\left[\mathrm{C}_{3} \mathrm{mpy}\right]\left[\mathrm{PF}_{6}\right]$ & $<0.5$ & $>99$ & 312 & 12640 & & 26 \\
\hline \multirow[t]{2}{*}[\mathrm{C}_{3}\mathrm{mpyrr}]{$\left[\mathrm{PF}_{6}\right]$} & $<0.5$ & $>99$ & 383 & 3410 & $\begin{array}{l}T_{\text {trans1 }}=346.6 \mathrm{~K}, \Delta h_{\text {trans } 1}=2810 \mathrm{~J} \mathrm{~mol}^{-1}, T_{\text {trans } 2}=359.5 \mathrm{~K} \text {, } \\
\Delta h_{\text {trans } 2}=2310 \mathrm{~J} \mathrm{~mol}^{-1}\end{array}$ & 26 \\
\hline & & & 386 & 6565 & $T_{\text {trans1 }}=355.2 \mathrm{~K}, T_{\text {trans } 2}=370.2 \mathrm{~K}$ & 53 \\
\hline$\left[\mathrm{C}_{3} \mathrm{mpip}\right]\left[\mathrm{PF}_{6}\right]$ & $<0.5$ & $>99$ & 368 & 5110 & $\begin{array}{l}T_{\text {trans } 1}=311.7 \mathrm{~K}, \Delta h_{\text {trans } 1}=8080 \mathrm{~J} \mathrm{~mol}^{-1}, T_{\text {trans2 }}=352.4 \mathrm{~K}, \\
\Delta h_{\text {trans } 2}=2740 \mathrm{~J} \mathrm{~mol}^{-1}\end{array}$ & 26 \\
\hline
\end{tabular}
$\left[\mathrm{C}_{3} \mathrm{mpy}\right]\left[\mathrm{PF}_{6}\right]-\left[\mathrm{C}_{3} \mathrm{mim}\right]\left[\mathrm{PF}_{6}\right]$ binary system are somewhat

Table 1. Enthalpies of Fusion and of Solid-Solid Transitions from the Literature ${ }^{26,52,53}$ for the Pure Compounds $\left[\mathrm{C}_{3} \mathrm{mim}\right]\left[\mathrm{PF}_{6}\right],\left[\mathrm{C}_{3} \mathrm{mpy}\right]\left[\mathrm{PF}_{6}\right],\left[\mathrm{C}_{3} \mathrm{mpyrr}\right]\left[\mathrm{PF}_{6}\right]$, and $\left[\mathrm{C}_{3} \mathrm{mpip}\right]\left[\mathrm{PF}_{6}\right]$ 
(a)

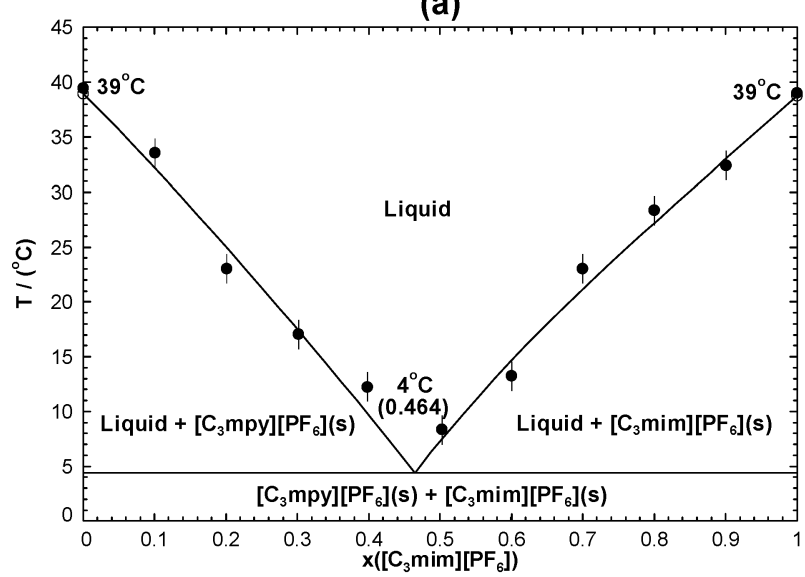

(c)

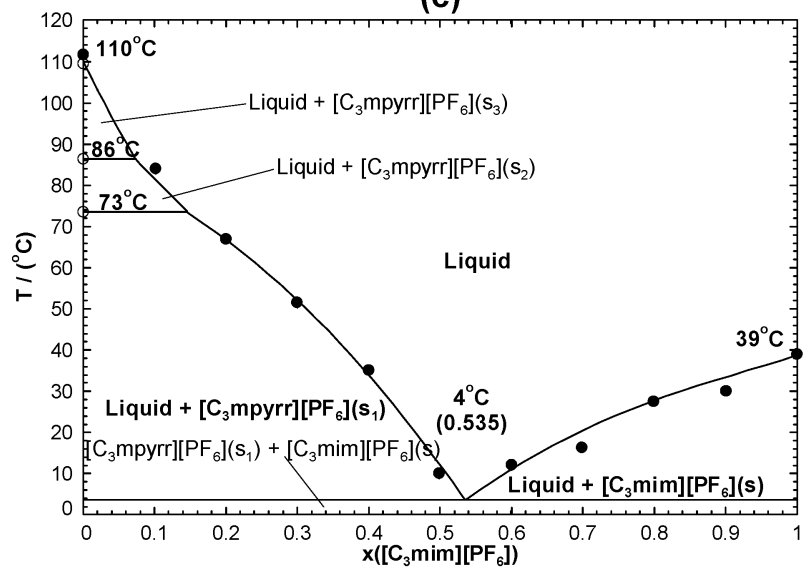

(b)

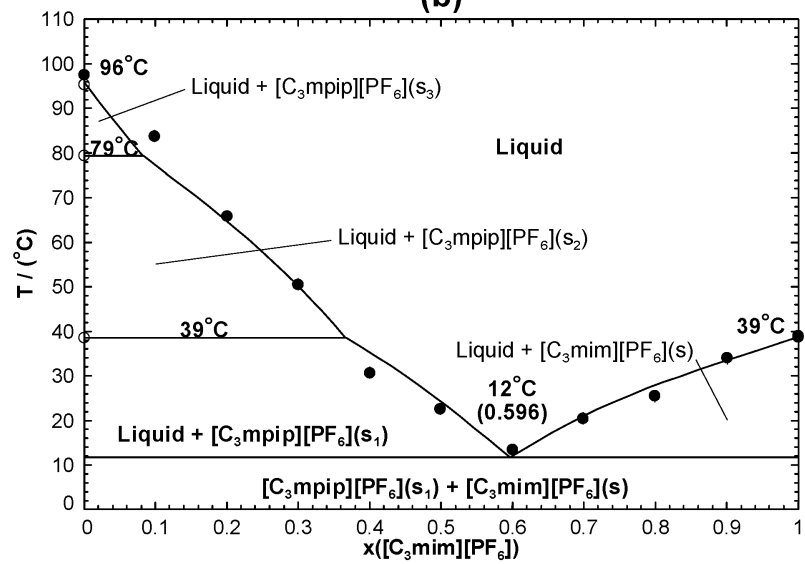

(d)

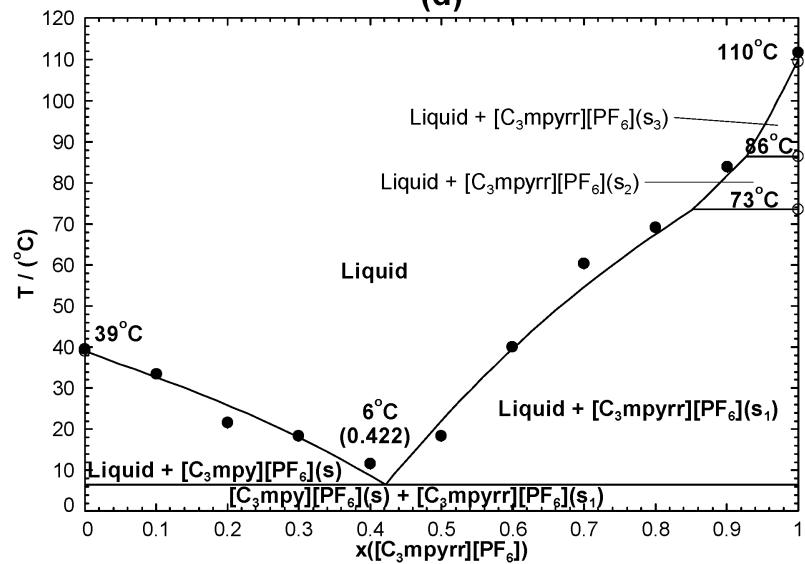

(e)

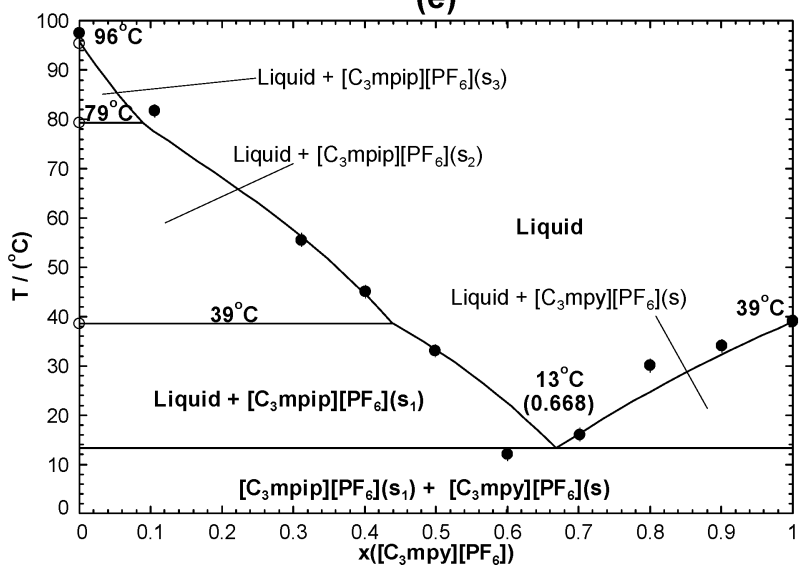

Figure 3. Calculated binary phase diagrams with a simple eutectic behavior, temperature versus mole fraction of the second component: (a) $\left[\mathrm{C}_{3} \mathrm{mpy}\right]\left[\mathrm{PF}_{6}\right]-\left[\mathrm{C}_{3} \mathrm{mim}\right]\left[\mathrm{PF}_{6}\right],(\mathrm{b})\left[\mathrm{C}_{3} \mathrm{mpip}\right]\left[\mathrm{PF}_{6}\right]-\left[\mathrm{C}_{3} \mathrm{mim}\right]\left[\mathrm{PF}_{6}\right],(\mathrm{c})\left[\mathrm{C}_{3} \mathrm{mpyrr}\right]\left[\mathrm{PF}_{6}\right]-\left[\mathrm{C}_{3} \mathrm{mim}\right]\left[\mathrm{PF}_{6}\right],(\mathrm{d})\left[\mathrm{C}_{3} \mathrm{mpy}\right]\left[\mathrm{PF}_{6}\right]-\left[\mathrm{C}_{3} \mathrm{mpyrr}\right]\left[\mathrm{PF}_{6}\right]$, and (e) $\left[\mathrm{C}_{3} \mathrm{mpip}\right]\left[\mathrm{PF}_{6}\right]-\left[\mathrm{C}_{3} \mathrm{mpy}\right]\left[\mathrm{PF}_{6}\right]$. Experimental data are from Maximo et al. ${ }^{26}$ (optical microscopy $(\bullet)$, DSC (O)).

smaller in amplitude than those for the four other binary systems with a simple eutectic behavior. This was expected since the former system, which involves two aromatic cations, should display smaller deviations from ideality than the latter, which all involve an aromatic and a nonaromatic cation.

4.2.2. Phase Diagram with Complete Solid Solution. The phase diagram of the $\left[\mathrm{C}_{3} \mathrm{mpip}\right]\left[\mathrm{PF}_{6}\right]-\left[\mathrm{C}_{3} \mathrm{mpyrr}\right]\left[\mathrm{PF}_{6}\right]$ binary system has been measured by Maximo et al. ${ }^{26}$ using optical microscopy, DSC, and powder X-ray diffractometry of the solid phase. No intermediate compound has been observed. As shown in Figure $4 a$, the measured limiting slopes (thin red lines) of the $\left[\mathrm{C}_{3} \mathrm{mpip}\right]\left[\mathrm{PF}_{6}\right]$ and $\left[\mathrm{C}_{3} \mathrm{mpyrr}\right]\left[\mathrm{PF}_{6}\right]$ liquidus curves substantially disagree with eq 15 , which assumes no solid solubility:

$$
\left(\frac{\mathrm{d} T}{\mathrm{~d} x_{m}^{\text {liquidus }}}\right)=\frac{R T_{\text {fusion }(m)}^{2}}{\Delta h_{\text {fusion }(m)}^{0}}\left[\text { at } x_{m}=1\right]
$$

where $R$ is the gas constant, and $T_{\text {fusion(m) }}$ and $\Delta h_{\text {fusion(m) }}^{0}$ are, respectively, the temperature of fusion and the molar enthalpy 
Table 2. Optimized Gibbs Energy of Reaction 1 for the Eutectic-Type Phase Diagrams

\begin{tabular}{cc} 
binary system & optimized $\Delta g_{\mathrm{AB} /\left[\mathrm{PF}_{6}\right]}\left(\mathrm{J} \mathrm{mol}{ }^{-1}\right)$ \\
{$\left[\mathrm{C}_{3} \mathrm{mpy}\right]\left[\mathrm{PF}_{6}\right]-\left[\mathrm{C}_{3} \mathrm{mim}\right]\left[\mathrm{PF}_{6}\right]$} & $205.0-163.2 \chi_{\left[\mathrm{C}_{3} \mathrm{mpy}\right]\left[\mathrm{C}_{3} \mathrm{mim}\right]}$ \\
{$\left[\mathrm{C}_{3} \mathrm{mpip}\right]\left[\mathrm{PF}_{6}\right]-\left[\mathrm{C}_{3} \mathrm{mim}\right]\left[\mathrm{PF}_{6}\right]$} & $-460.2+677.8 \chi_{\left[\mathrm{C}_{3} \mathrm{mpip}\right]\left[\mathrm{C}_{3} \mathrm{mim}\right]}+$ \\
{$\left[\mathrm{C}_{3} \mathrm{mpyrr}\right]\left[\mathrm{PF}_{6}\right]-\left[\mathrm{C}_{3} \mathrm{mim}\right]\left[\mathrm{PF}_{6}\right]$} & $-502.5 \chi_{\left[\mathrm{C}_{3} \mathrm{mim}\right]\left[\mathrm{C}_{3} \mathrm{mpip}\right]}$ \\
{$\left[\mathrm{C}_{3} \mathrm{mpy}\right]\left[\mathrm{PF}_{6}\right]-\left[\mathrm{C}_{3} \mathrm{mpyrr}\right]\left[\mathrm{PF}_{6}\right]$} & $-192.3+661.1 \chi_{\left[\mathrm{C}_{3} \mathrm{mpyrr}\right]\left[\mathrm{C}_{3} \mathrm{mim}\right]}+$ \\
& $\left.502.1 \chi_{\left[\mathrm{C}_{3} \mathrm{mpyrr}\right]\left[\mathrm{C}_{3} \mathrm{mpy}\right]}+\mathrm{C}_{3} \mathrm{mpyrr}\right]$ \\
{$\left[\mathrm{C}_{3} \mathrm{mpip}\right]\left[\mathrm{PF}_{6}\right]-\left[\mathrm{C}_{3} \mathrm{mpy}\right]\left[\mathrm{PF}_{6}\right]$} & $715.5 \chi_{\left[\mathrm{C}_{3} \mathrm{mpip}\right]\left[\mathrm{C}_{3} \mathrm{mpy}\right]}$ \\
\hline
\end{tabular}

of fusion of the pure salt $m$. Therefore, this system exhibits at least some solid solubility.

Maximo et al. $^{26}$ reported an extensive solid solution over the entire composition range for the $\left[\mathrm{C}_{3} \mathrm{mpip}\right]\left[\mathrm{PF}_{6}\right]-\left[\mathrm{C}_{3} \mathrm{mpyrr}\right]$ $\left[\mathrm{PF}_{6}\right]$ binary system. Common-anion ionic liquid binary systems that exhibit full solid solutions are rather uncommon. More recently, Teles et al. ${ }^{23}$ reported also an extensive solid solution for the $\left[\mathrm{C}_{2} \mathrm{mpyrr}\right]\left[\mathrm{N}\left(\mathrm{C}_{4} \mathrm{~F}_{9} \mathrm{SO}_{2}\right)_{2}\right]-\left[\mathrm{C}_{4} \mathrm{mpyrr}\right][\mathrm{N}$ $\left.\left(\mathrm{C}_{4} \mathrm{~F}_{9} \mathrm{SO}_{2}\right)_{2}\right]$ binary system. Maximo et al. ${ }^{26}$ observed on their DSC thermograms a single endothermic transition upon heating, which suggests the presence of a continuous solid solution. These authors further confirmed the formation of a monophasic solid phase by powder X-ray diffraction at 298.15 $\mathrm{K}$ (solid solution $\mathrm{C}\left(s_{3}-s_{3}\right)$ in Figure 4$)$ and determined the crystallographic structure of the $\left[\mathrm{C}_{3} \mathrm{mpip}\right]\left[\mathrm{PF}_{6}\right]$ pure compound by single crystal X-ray diffraction at $180 \mathrm{~K}$ (allotrope $\left(s_{1}\right)$ ). This compound is monoclinic (space group $P 2_{1} / c$ ) with 8 formula units per unit cell and unit cell angles $\alpha=90^{\circ}, \beta=$ $109.466^{\circ}, \gamma=90^{\circ}$. Golding et al. ${ }^{53}$ reported crystallographic data for the $\left[\mathrm{C}_{3} \mathrm{mpyrr}\right]\left[\mathrm{PF}_{6}\right]$ pure compound at $123 \mathrm{~K}$ (allotrope $\left(s_{1}\right)$ ). This compound is monoclinic (space group $C 2 / c$ ) with 36 formula units per unit cell and unit cell angles $\alpha$ $=90^{\circ}, \beta=109.797^{\circ}, \gamma=90^{\circ}$. Thus, the low-temperature allotropes $\left(s_{1}\right)$ of $\left[\mathrm{C}_{3} \mathrm{mpip}\right]\left[\mathrm{PF}_{6}\right]$ and $\left[\mathrm{C}_{3} \mathrm{mpyrr}\right]\left[\mathrm{PF}_{6}\right]$ have monoclinic unit cells with very similar crystallographic axes angles. Maximo et al. ${ }^{26}$ suggested that the crystalline structure of $\left[\mathrm{C}_{3} \mathrm{mpyrr}\right]\left[\mathrm{PF}_{6}\right]$, which corresponds to a bigger crystal volume, may act as a host-structure to accommodate the crystal structure of $\left[\mathrm{C}_{3} \mathrm{mpip}\right]\left[\mathrm{PF}_{6}\right]$, thus leading to the formation of a continuous solid solution. It can thus be concluded that the high-temperature allotropes $\left(s_{3}\right)$ of $\left[\mathrm{C}_{3} \mathrm{mpip}\right]\left[\mathrm{PF}_{6}\right]$ and $\left[\mathrm{C}_{3} \mathrm{mpyrr}\right]\left[\mathrm{PF}_{6}\right]$ form an extensive solid solution over the entire composition range, and that the lowtemperature allotropes $\left(s_{1}\right)$ most likely have the same behavior. It is therefore reasonable to assume that the intermediatetemperature allotropes $\left(s_{2}\right)$ are also fully miscible. In order to (a)

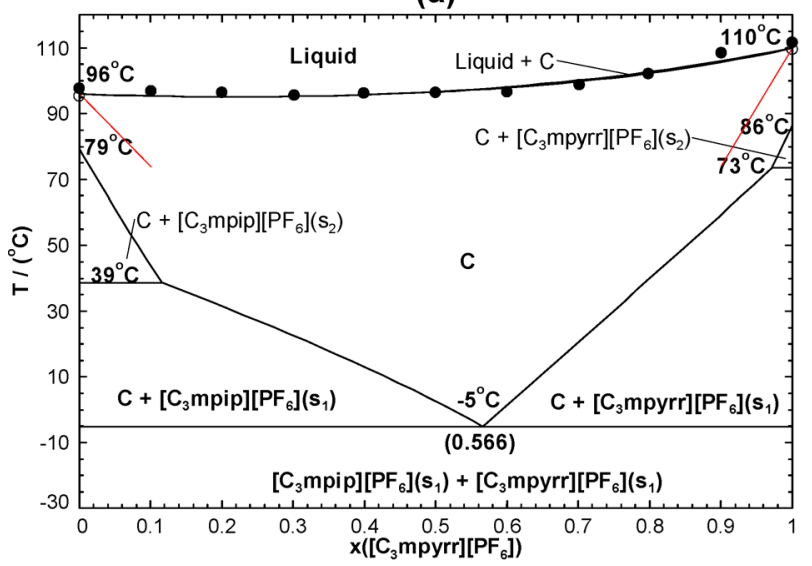

(b)

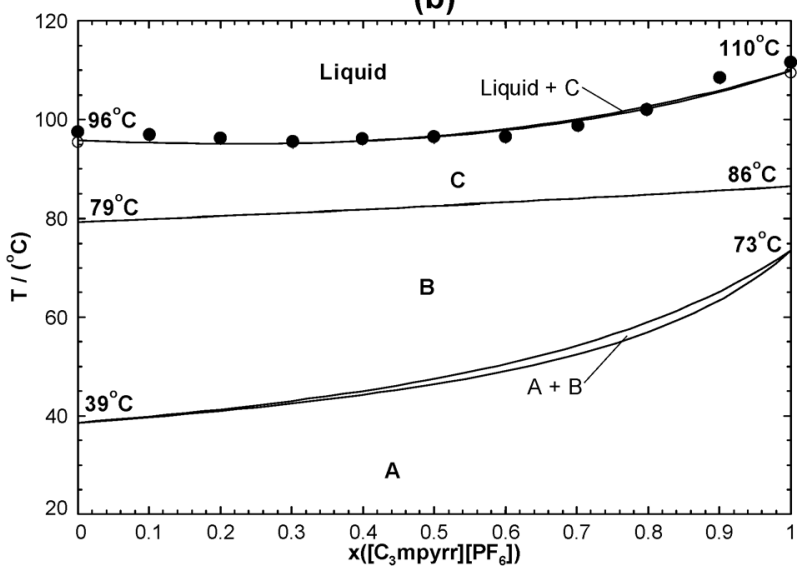

(c)

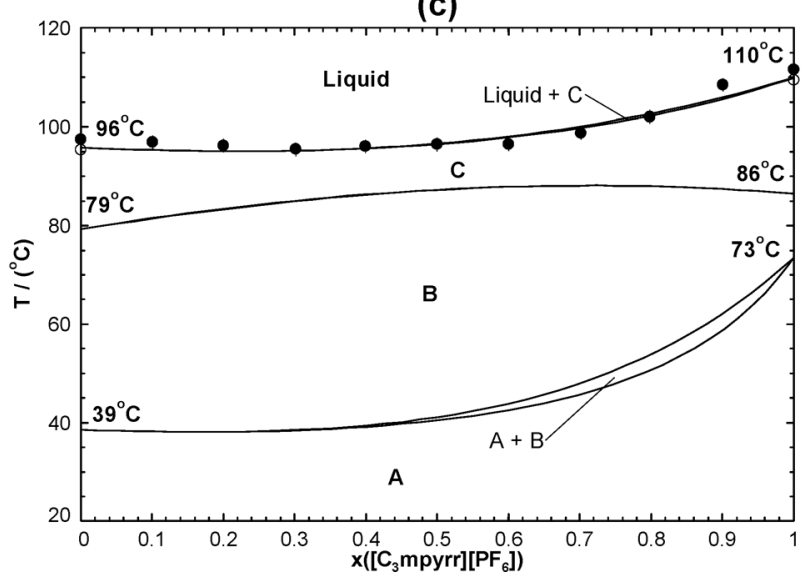

Figure 4. Calculated $\left[\mathrm{C}_{3} \mathrm{mpip}\right]\left[\mathrm{PF}_{6}\right]-\left[\mathrm{C}_{3} \mathrm{mpyrr}\right]\left[\mathrm{PF}_{6}\right]$ phase diagram, temperature versus mole fraction of $\left[\mathrm{C}_{3} \mathrm{mpyrr}\right]\left[\mathrm{PF}_{6}\right]:(\mathrm{a})$ first scenario $($ the limiting liquidus slopes calculated from eq 15 are shown as thin red lines), (b) second scenario, and (c) final. Notations: $\mathrm{A}=\left\{\left[\mathrm{C}_{3} \mathrm{mpip}\right]\left[\mathrm{PF}_{6}\right]\left(s_{1}\right)-\right.$ $\left.\left[\mathrm{C}_{3} \mathrm{mpyrr}\right]\left[\mathrm{PF}_{6}\right]\left(s_{1}\right)\right\}(\mathrm{ss}) ; \mathrm{B}=\left\{\left[\mathrm{C}_{3} \mathrm{mpip}\right]\left[\mathrm{PF}_{6}\right]\left(s_{2}\right)-\left[\mathrm{C}_{3} \mathrm{mpyrr}\right]\left[\mathrm{PF}_{6}\right]\left(s_{2}\right)\right\}(\mathrm{ss}) ; \mathrm{C}=\left\{\left[\mathrm{C}_{3} \mathrm{mpip}\right]\left[\mathrm{PF}_{6}\right]\left(s_{3}\right)-\left[\mathrm{C}_{3} \mathrm{mpyrr}\right]\left[\mathrm{PF}_{6}\right]\left(s_{3}\right)\right\}(\mathrm{ss})$. Experimental data are from Maximo et al. ${ }^{26}$ (optical microscopy $(\bullet)$, DSC (O)). 
check this hypothesis, two different scenarios were considered in the present work to model the phase diagram of the $\left[\mathrm{C}_{3} \mathrm{mpip}\right]\left[\mathrm{PF}_{6}\right]-\left[\mathrm{C}_{3} \mathrm{mpyrr}\right]\left[\mathrm{PF}_{6}\right]$ binary system. The first scenario assumes a negligible solid solubility between the low-temperature allotropes $\left(s_{1}-s_{1}\right)$ and also between the intermediate-temperature allotropes $\left(s_{2}-s_{2}\right)$ (Figure $4 \mathrm{a}$ ). The second scenario assumes a continuous solid solution between the low-temperature allotropes $\left(s_{1}-s_{1}\right)$ and also between the intermediate-temperature allotropes $\left(s_{2}-s_{2}\right)$ (Figure $4 \mathrm{~b}$ ). As a first approximation, in the latter scenario, the same excess Gibbs energy as for the high-temperature $\left(s_{3}-s_{3}\right)$ solid solution (which was optimized on the basis of the experimental data of Maximo et al. $\left.{ }^{26}\right)$ was used for both the low-temperature $\left(s_{1}-\right.$ $\left.s_{1}\right)$ and the intermediate-temperature $\left(s_{2}-s_{2}\right)$ solid solutions. The two pure compounds have very similar cation structures (only differing by one carbon atom) and also similar crystal structures. Thus, the binary liquid was assumed to be ideal. That is

$$
\Delta g_{\left[\mathrm{C}_{3} \mathrm{mpip}\right]\left[\mathrm{C}_{3} \mathrm{mpyrr}_{/\left[\mathrm{PF}_{6}\right]}\right.}=0
$$

The various solid solutions were described with the Compound Energy Formalism (CEF). Figure 4 displays the calculated phase diagram along with the measurements from Maximo et al., according to the first scenario (Figure 4a) and the second scenario (Figure $4 \mathrm{~b}$ ). The calculated phase diagram for the first scenario displays the high-temperature $\left(s_{3}-s_{3}\right)$ solid solution along with the eutectoid reaction $\left\{\left[\mathrm{C}_{3} \mathrm{mpip}\right]\right.$ $\left.\left[\mathrm{PF}_{6}\right]\left(s_{3}\right)-\left[\mathrm{C}_{3} \mathrm{mpyrr}\right]\left[\mathrm{PF}_{6}\right]\left(s_{3}\right)\right\}(\mathrm{ss})=\left[\mathrm{C}_{3} \mathrm{mpip}\right]\left[\mathrm{PF}_{6}\right]\left(s_{1}\right)+$ $\left[\mathrm{C}_{3} \mathrm{mpyrr}\right]\left[\mathrm{PF}_{6}\right]\left(s_{1}\right)$ at $-5{ }^{\circ} \mathrm{C}$ and $56.6 \mathrm{~mol} \%$ [ $\left.\mathrm{C}_{3} \mathrm{mpyrr}\right]-$ $\left[\mathrm{PF}_{6}\right]$. On the other hand, there are three distinct areas corresponding to the high-temperature $\left(s_{3}-s_{3}\right)$, intermediatetemperature $\left(s_{2}-s_{2}\right)$ and low-temperature $\left(s_{1}-s_{1}\right)$ solid solutions in the calculated phase diagram for the second scenario. As will be shown later, the second scenario allows to best reproduce the DSC measurements performed in the $\left[\mathrm{C}_{3} \mathrm{mim}\right]\left[\mathrm{PF}_{6}\right]-\left[\mathrm{C}_{3} \mathrm{mpip}\right]\left[\mathrm{PF}_{6}\right]-\left[\mathrm{C}_{3} \mathrm{mpyrr}\right]\left[\mathrm{PF}_{6}\right]$ ternary system. The final optimized excess Gibbs energy $\left(G^{\mathrm{E}}\right)$ of each solid solution is given in Table 3 . These are small positive

Table 3. Optimized Excess Gibbs Energies of the Solid Solutions in the $\left[\mathrm{C}_{3} \mathrm{mpip}\right]\left[\mathrm{PF}_{6}\right]-\left[\mathrm{C}_{3} \mathrm{mpyrr}\right]\left[\mathrm{PF}_{6}\right]$ binary System $^{a}$

\begin{tabular}{cc}
\multicolumn{1}{c}{ solid solution } & optimized $G^{\mathrm{E}}\left(\mathrm{J} \mathrm{mol}^{-1}\right)$ \\
high-temperature $\left(s_{3}-s_{3}\right)$ & $217.6 \times y_{\left[\mathrm{C}_{3} \mathrm{mpip}\right]^{+}}^{\mathrm{C}} \times y_{\left[\mathrm{C}_{3} \mathrm{mpyrr}\right]^{+}}^{\mathrm{C}}$ \\
intermediate-temperature $\left(s_{2}-s_{2}\right)$ & $83.7 \times y_{\left[\mathrm{C}_{3} \mathrm{mpip}\right]^{+}}^{\mathrm{C}} \times y_{\left[\mathrm{C}_{3} \mathrm{mpyrr}\right]^{+}}^{\mathrm{C}}$ \\
low-temperature $\left(s_{1}-s_{1}\right)$ & $502.1 \times y_{\left[\mathrm{C}_{3} \mathrm{mpip}\right]^{+}}^{\mathrm{C}} \times y_{\left[\mathrm{C}_{3} \mathrm{mpyrr}\right]^{+}}^{\mathrm{C}}$
\end{tabular}

$a y_{i}^{C}$ is the site fraction of species $i$ on the cationic sublattice C.

regular interaction parameters. The final calculated phase diagram of the $\left[\mathrm{C}_{3} \mathrm{mpip}\right]\left[\mathrm{PF}_{6}\right]-\left[\mathrm{C}_{3} \mathrm{mpyrr}\right]\left[\mathrm{PF}_{6}\right]$ binary system with the interaction parameters from Table 3 is shown in Figure 4c. There is a minimum at $95{ }^{\circ} \mathrm{C}$ and $22 \mathrm{~mol}$ $\%\left[\mathrm{C}_{3} \mathrm{mpyrr}\right]\left[\mathrm{PF}_{6}\right]$. The temperature of the minimum is lower than the melting temperatures of the pure compounds.

4.3. Ternary Subsystems. The quaternary system investigated consists of the four following ternary subsystems: (1) $\left[\mathrm{C}_{3} \mathrm{mim}\right]\left[\mathrm{PF}_{6}\right]-\left[\mathrm{C}_{3} \mathrm{mpip}\right]\left[\mathrm{PF}_{6}\right]-\left[\mathrm{C}_{3} \mathrm{mpyrr}\right]\left[\mathrm{PF}_{6}\right]$, (2) $\left[\mathrm{C}_{3} \mathrm{mpy}\right]\left[\mathrm{PF}_{6}\right]-\left[\mathrm{C}_{3} \mathrm{mpip}\right]\left[\mathrm{PF}_{6}\right]-\left[\mathrm{C}_{3} \mathrm{mpyrr}\right]\left[\mathrm{PF}_{6}\right]$, $\left[\mathrm{C}_{3} \mathrm{mpip}\right]\left[\mathrm{PF}_{6}\right]-\left[\mathrm{C}_{3} \mathrm{mpy}\right]\left[\mathrm{PF}_{6}\right]-\left[\mathrm{C}_{3} \mathrm{mim}\right]\left[\mathrm{PF}_{6}\right]$, and $(4)$ $\left[\mathrm{C}_{3} \mathrm{mpyrr}\right]\left[\mathrm{PF}_{6}\right]-\left[\mathrm{C}_{3} \mathrm{mpy}\right]\left[\mathrm{PF}_{6}\right]-\left[\mathrm{C}_{3} \mathrm{mim}\right]\left[\mathrm{PF}_{6}\right]$. Since systems 1 and 2 both include the $\left[\mathrm{C}_{3} \mathrm{mpip}\right]\left[\mathrm{PF}_{6}\right]$ and $\left[\mathrm{C}_{3} \mathrm{mpyrr}\right]$ -
$\left[\mathrm{PF}_{6}\right]$ components, they will display at least a complete hightemperature binary solid solution $\left(s_{3}-s_{3}\right)$. On the other hand, systems 3 and 4 exhibit a negligible solid solubility. Two isoplethal sections were measured in each of the four ternary systems using DSC, with most of the measurements performed for systems 1 and 3.

Liquidus projections of the various ternary subsystems were calculated (see Figures 5, 7, 9, and 11), and the region of

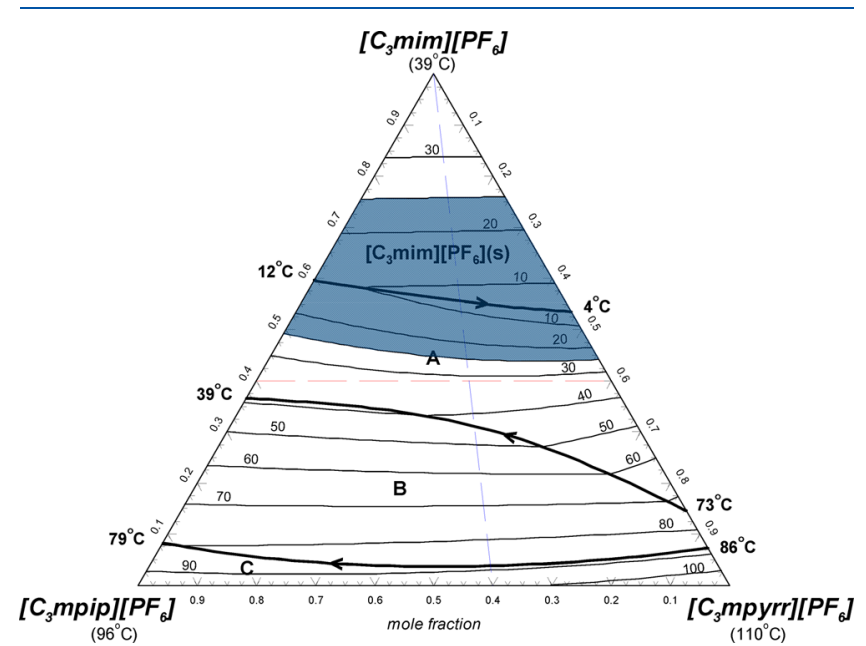

Figure 5. Calculated liquidus projection of the $\left[\mathrm{C}_{3} \mathrm{mim}\right]\left[\mathrm{PF}_{6}\right]-$ $\left[\mathrm{C}_{3}\right.$ mpip $]\left[\mathrm{PF}_{6}\right]-\left[\mathrm{C}_{3} \mathrm{mpyrr}\right]\left[\mathrm{PF}_{6}\right]$ system. Notations: $\mathrm{A}=\left\{\left[\mathrm{C}_{3} \mathrm{mpip}\right]-\right.$ $\left.\left[\mathrm{PF}_{6}\right]\left(s_{1}\right)-\left[\mathrm{C}_{3} \mathrm{mpyrr}\right]\left[\mathrm{PF}_{6}\right]\left(s_{1}\right)\right\}(\mathrm{ss}) ; \mathrm{B}=\left\{\left[\mathrm{C}_{3} \mathrm{mpip}\right]\left[\mathrm{PF}_{6}\right]\left(s_{2}\right)-\right.$ $\left.\left[\mathrm{C}_{3} \mathrm{mpyrr}\right]\left[\mathrm{PF}_{6}\right]\left(s_{2}\right)\right\}(\mathrm{ss}) ; \mathrm{C}=\left\{\left[\mathrm{C}_{3} \mathrm{mpip}\right]\left[\mathrm{PF}_{6}\right]\left(s_{3}\right)-\left[\mathrm{C}_{3} \mathrm{mpyrr}\right]-\right.$ $\left.\left[\mathrm{PF}_{6}\right]\left(s_{3}\right)\right\}(\mathrm{ss})$. The isoplethal sections at constant $40 \mathrm{~mol} \%$ $\left[\mathrm{C}_{3} \mathrm{mim}\right]\left[\mathrm{PF}_{6}\right]$ (red dashed line) and at a constant molar ratio $\left[\mathrm{C}_{3} \mathrm{mpyrr}\right]\left[\mathrm{PF}_{6}\right] /\left(\left[\mathrm{C}_{3} \mathrm{mpyrr}\right]\left[\mathrm{PF}_{6}\right]+\left[\mathrm{C}_{3} \mathrm{mpip}\right]\left[\mathrm{PF}_{6}\right]\right)$ of 0.60 (blue dashed line) are shown schematically. The region of composition corresponding to room temperature ionic liquid (RTIL) mixtures is highlighted.

compositions corresponding to room temperature ionic liquid (RTIL) mixtures is highlighted. As discussed previously, $\left[\mathrm{C}_{3} \mathrm{mpip}\right]\left[\mathrm{PF}_{6}\right]$ and $\left[\mathrm{C}_{3} \mathrm{mpyrr}\right]\left[\mathrm{PF}_{6}\right]$ have very similar cation structures and also similar crystal structures. Thus, the thermodynamic properties of the ternary subsystems 1 and 2 (which include both components) were calculated from the optimized model parameters for the three binary subsystems using a Kohler-Toop-like (asymmetric) interpolation method (see Figure $1 \mathrm{~b}$ ), with $\left[\mathrm{C}_{3} \mathrm{mim}\right]\left[\mathrm{PF}_{6}\right]$ (or $\left[\mathrm{C}_{3} \mathrm{mpy}\right]\left[\mathrm{PF}_{6}\right]$ ) as the asymmetric component. For the ternary subsystems 3 and 4, a Kohler-like (symmetric) interpolation method was used (see Figure 1a) . A similar approach has been used successfully for various multicomponent common-anion inorganic salt systems (chlorides and fluorides). ${ }^{46-48,54-58}$ The cations of each system were separated into different chemical groups: alkali cations $\left(\mathrm{Li}^{+}, \mathrm{Na}^{+}, \mathrm{K}^{+}, \mathrm{Rb}^{+}, \mathrm{Cs}^{+}\right)$in a first group, alkalineearth $\left(\mathrm{Mg}^{2+}, \mathrm{Ca}^{2+}, \mathrm{Sr}^{2+}, \mathrm{Ba}^{2+}\right)$ and divalent metal $\left(\mathrm{Mn}^{2+}, \mathrm{Fe}^{2+}\right.$, $\left.\mathrm{Co}^{2+}, \mathrm{Ni}^{2+}, \mathrm{Zn}^{2+}\right)$ cations in a second group, and trivalent metal cations $\left(\mathrm{Fe}^{3+}, \mathrm{Al}^{3+}\right)$ in a third group. If the three cations of a ternary common-anion salt system all belonged to the same group or to three different groups, then a symmetric interpolation was used. On the other hand, if two cations were in the same group and if the third cation belonged to another group, an asymmetric interpolation was used instead with the salt component involving the latter cation as the asymmetric component. With this systematic approach, the predictions for the ternary common-anion salt system were 
always more satisfactory. That is, agreement between the calculations and the available experimental data was substantially better, and when one or more ternary parameters were required to best reproduce the ternary measurements, the number and amplitude of these ternary parameters were always smaller. The same methodology was used for the quaternary ionic liquid system investigated in the present work: $\left[\mathrm{C}_{3} \text { mpip }\right]^{+}$and $\left[\mathrm{C}_{3} \text { mpyrr }\right]^{+}$belong to the same group owing to their close similarity, $\left[\mathrm{C}_{3} \mathrm{mim}\right]^{+}$is in a second group, and $\left[\mathrm{C}_{3} \mathrm{mpy}\right]^{+}$belongs to a third group. As explained previously, the optimized model parameters $\Delta g_{\mathrm{AB} /\left[\mathrm{PF}_{6}\right]}$ for the six binary subsystems of the $\left[\mathrm{C}_{3} \mathrm{mim}\right]\left[\mathrm{PF}_{6}\right]-\left[\mathrm{C}_{3} \mathrm{mpy}\right]\left[\mathrm{PF}_{6}\right]-\left[\mathrm{C}_{3} \mathrm{mpyrr}\right]$ $\left[\mathrm{PF}_{6}\right]-\left[\mathrm{C}_{3} \mathrm{mpip}\right]\left[\mathrm{PF}_{6}\right]$ system are relatively small in amplitude, and the quaternary liquid is thus close to ideal. Therefore, the predictions in the various ternary subsystems, based on the optimized binary model parameters, will not be much affected by the choice of the method of interpolation. However, putting the $\left[\mathrm{C}_{3} \text { mpip }\right]^{+}$and $\left[\mathrm{C}_{3} \text { mpyrr }\right]^{+}$cations in the same group gave somewhat better predictions in the $\left[\mathrm{C}_{3} \mathrm{mim}\right]\left[\mathrm{PF}_{6}\right]-\left[\mathrm{C}_{3} \mathrm{mpip}\right]$ $\left[\mathrm{PF}_{6}\right]-\left[\mathrm{C}_{3} \mathrm{mpyrr}\right]\left[\mathrm{PF}_{6}\right]$ ternary subsystem, for which several DSC measurements were conducted.

4.3.1. $\left[C_{3}\right.$ mim $]\left[P F_{6}\right]-\left[C_{3}\right.$ mpip $]\left[P F_{6}\right]-\left[C_{3}\right.$ mpyrr $]\left[P F_{6}\right]$ System. The calculated liquidus projection of the $\left[\mathrm{C}_{3} \mathrm{mim}\right]$ $\left[\mathrm{PF}_{6}\right]-\left[\mathrm{C}_{3} \mathrm{mpip}\right]\left[\mathrm{PF}_{6}\right]-\left[\mathrm{C}_{3} \mathrm{mpyrr}\right]\left[\mathrm{PF}_{6}\right]$ system is shown in Figure 5 . The second scenario, which assumes a continuous solid solution between the low-temperature allotropes $\left(s_{1}-s_{1}\right)$ and also between the intermediate-temperature allotropes $\left(s_{2}-\right.$ $\left.s_{2}\right)$ of $\left[\mathrm{C}_{3} \mathrm{mpip}\right]\left[\mathrm{PF}_{6}\right]$ and $\left[\mathrm{C}_{3} \mathrm{mpyrr}\right]\left[\mathrm{PF}_{6}\right]$, was finally favored on the basis of the available ternary data; detailed explanations are given in the Supporting Information. No ternary excess parameter was included for the liquid phase, and the excess Gibbs energies of the low-temperature $\left(s_{1}-s_{1}\right)$ and intermediate-temperature $\left(s_{2}-s_{2}\right)$ binary solid solutions were adjusted (see Table 3 ) in order to best reproduce the ternary data. The minimum liquidus temperature corresponds to the binary eutectic reaction liquid $=\left[\mathrm{C}_{3} \mathrm{mim}\right]\left[\mathrm{PF}_{6}\right]+\left[\mathrm{C}_{3} \mathrm{mpyrr}\right]$ $\left[\mathrm{PF}_{6}\right]\left(s_{1}\right)$ at $4{ }^{\circ} \mathrm{C}$. The isoplethal sections at constant $40 \mathrm{~mol} \%$ $\left[\mathrm{C}_{3} \mathrm{mim}\right]\left[\mathrm{PF}_{6}\right]$ (red dashed line in Figure 5) and at a constant molar ratio $\left[\mathrm{C}_{3} \mathrm{mpyrr}\right]\left[\mathrm{PF}_{6}\right] /\left(\left[\mathrm{C}_{3} \mathrm{mpyrr}\right]\left[\mathrm{PF}_{6}\right]+\left[\mathrm{C}_{3} \mathrm{mpip}\right]-\right.$ $\left[\mathrm{PF}_{6}\right]$ ) of 0.60 (blue dashed line in Figure 5) were measured by DSC, and the calculations are compared to the measurements in Figure 6a,b, respectively. The filled circles in Figure $6 \mathrm{~b}$ correspond to a ternary mixture, for which three consecutive heating/cooling cycles were used. For all other data points in Figure $6 \mathrm{a}, \mathrm{b}$, one cooling run was followed by one heating run. Two series of experiments were performed in the isoplethal section at constant $40 \mathrm{~mol} \%\left[\mathrm{C}_{3} \mathrm{mim}\right]\left[\mathrm{PF}_{6}\right]$ (Figure $6 \mathrm{a})$, and problems of reproducibility were encountered. In order to better interpret these measurements, the phase diagram has been divided into three approximate temperature zones (zones 1, 2, and 3). Zone 1 corresponds to the measured liquidus temperatures: in principle, for a given sample, the last thermal transition upon heating should be the liquidus temperature. In Figure 6a, the binary data from Maximo et al. $^{26}$ at 0 and $60 \mathrm{~mol} \%\left[\mathrm{C}_{3} \mathrm{mpyrr}\right]\left[\mathrm{PF}_{6}\right]$ are also shown. The shift between the calculated and measured liquidus temperatures is sometimes close to $10^{\circ} \mathrm{C}$ but usually lower than $5{ }^{\circ} \mathrm{C}$, which is the corresponding shift for the binary mixture at $0 \mathrm{~mol}$ $\%\left[\mathrm{C}_{3} \mathrm{mpyrr}\right]\left[\mathrm{PF}_{6}\right]$. Note that the thermal transition measured at $37.5 \mathrm{~mol} \%\left[\mathrm{C}_{3} \mathrm{mim}\right]\left[\mathrm{PF}_{6}\right]$ (and at $37.5 \mathrm{~mol} \%$ $\left[\mathrm{C}_{3} \mathrm{mpyrr}\right]\left[\mathrm{PF}_{6}\right]$ ) (see Figure $6 \mathrm{~b}$ ) is also displayed in Figure $6 \mathrm{a}$ along with the corresponding calculated liquidus line

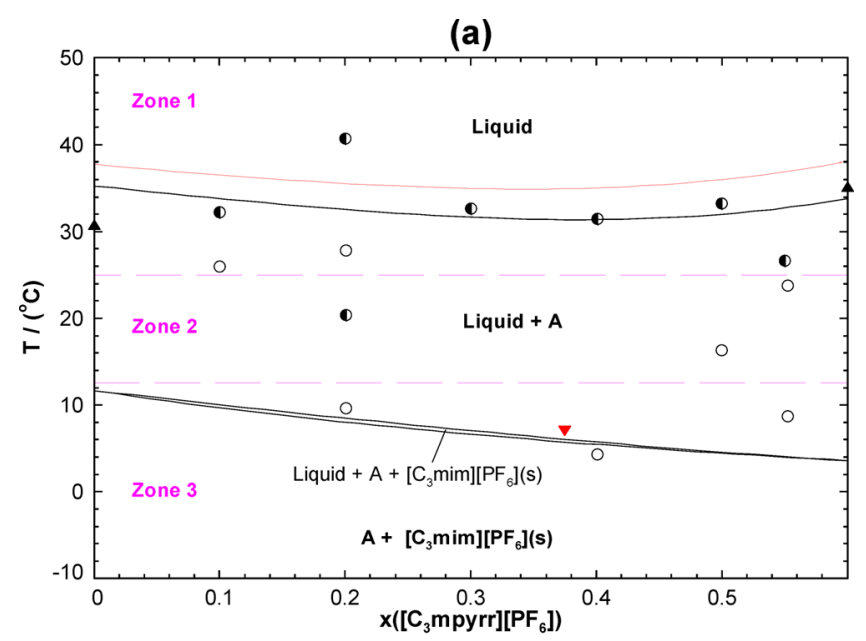

(b)

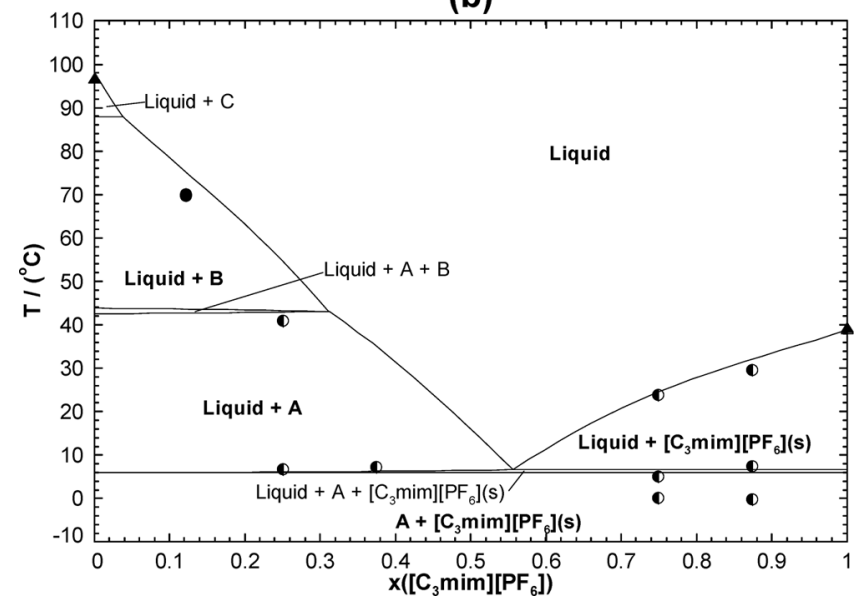

Figure 6. Calculated isoplethal sections in the $\left[\mathrm{C}_{3} \mathrm{mim}\right]\left[\mathrm{PF}_{6}\right]-$ $\left[\mathrm{C}_{3} \mathrm{mpip}\right]\left[\mathrm{PF}_{6}\right]-\left[\mathrm{C}_{3} \mathrm{mpyrr}\right]\left[\mathrm{PF}_{6}\right]$ system along with measurements. (a) At $40 \mathrm{~mol} \%\left[\mathrm{C}_{3} \mathrm{mim}\right]\left[\mathrm{PF}_{6}\right]$. The calculated liquidus line at 37.5 $\mathrm{mol} \%\left[\mathrm{C}_{3} \mathrm{mim}\right]\left[\mathrm{PF}_{6}\right]$ is also shown as a red dashed line. Experimental data are from the present work $(\boldsymbol{O}, 0)$, and Maximo et al. ${ }^{26}(\boldsymbol{\Delta})$. The thermal transition measured at $37.5 \mathrm{~mol} \%\left[\mathrm{C}_{3} \mathrm{mim}\right]\left[\mathrm{PF}_{6}\right]$ (and at $\left.37.5 \mathrm{~mol} \%\left[\mathrm{C}_{3} \mathrm{mpyrr}\right]\left[\mathrm{PF}_{6}\right]\right)$ and taken from part $\mathrm{b}$ is also shown $($ red $\boldsymbol{\nabla})$. (b) At a constant molar ratio $\left[\mathrm{C}_{3} \mathrm{mpyrr}\right]\left[\mathrm{PF}_{6}\right] /\left(\left[\mathrm{C}_{3} \mathrm{mpyrr}\right]\right.$ $\left.\left[\mathrm{PF}_{6}\right]+\left[\mathrm{C}_{3} \mathrm{mpip}\right]\left[\mathrm{PF}_{6}\right]\right)$ of 0.60 . Experimental data are from the present work $(\mathbf{D}, \mathbf{O})$ and Maximo et al. ${ }^{26}(\boldsymbol{\Delta}, \triangle)$. Notations: $\mathrm{A}=$ $\left\{\left[\mathrm{C}_{3} \mathrm{mpip}\right]\left[\mathrm{PF}_{6}\right]\left(s_{1}\right)-\left[\mathrm{C}_{3} \mathrm{mpyrr}\right]\left[\mathrm{PF}_{6}\right]\left(s_{1}\right)\right\}(\mathrm{ss}) ; \mathrm{B}=\left\{\left[\mathrm{C}_{3}\right.\right.$ mpip $]-$ $\left.\left[\mathrm{PF}_{6}\right]\left(s_{2}\right)-\left[\mathrm{C}_{3} \mathrm{mpyrr}\right]\left[\mathrm{PF}_{6}\right]\left(s_{2}\right)\right\}(\mathrm{ss}) ; \mathrm{C}=\left\{\left[\mathrm{C}_{3} \mathrm{mpip}\right]\left[\mathrm{PF}_{6}\right]\left(s_{3}\right)-\right.$ $\left.\left[\mathrm{C}_{3} \mathrm{mpyrr}\right]\left[\mathrm{PF}_{6}\right]\left(s_{3}\right)\right\}(\mathrm{ss})$.

(shown as a red dashed line). The lens-shaped region calculated at low temperatures remains virtually unchanged at $37.5 \mathrm{~mol} \%\left[\mathrm{C}_{3} \mathrm{mim}\right]\left[\mathrm{PF}_{6}\right]$. Zone 3 corresponds to the measured low-temperature thermal transitions. Agreement between the thermal transitions measured in this zone and the calculated lens-shaped region is satisfactory. Finally, zone 2 corresponds to the measured thermal transitions observed in the intermediate temperature range and possibly associated with metastable phase equilibria. These data points are not reproduced by the thermodynamic model. Metastable phase equilibria have already been observed for ionic liquid systems: for instance, during investigation by DSC of the $\left[\mathrm{C}_{4} \mathrm{mpyrr}\right] \mathrm{Cl}-$ $\left[\mathrm{C}_{4}\right.$ mpyrr $] \mathrm{Br}$ binary system, Stolarska et al. ${ }^{29}$ observed a thermal transition in the range $97-117^{\circ} \mathrm{C}$ for pure $\left[\mathrm{C}_{4} \mathrm{mpyrr}\right]$ $\mathrm{Cl}$ and most of the $\left[\mathrm{C}_{4}\right.$ mpyrr $] \mathrm{Cl}-\left[\mathrm{C}_{4}\right.$ mpyrr $] \mathrm{Br}$ binary 
mixtures. This was attributed to a possible polymorphism of $\left[\mathrm{C}_{4} \mathrm{mpyrr}\right] \mathrm{Cl}$, with the existence of two preferred conformations of the pyrrolidinium ions. However, no such thermal transition was observed in the $\left[\mathrm{C}_{4} \mathrm{mpyrr}\right] \mathrm{Cl}-\left[\mathrm{C}_{4} \mathrm{mpyrr}\right]\left[\mathrm{BF}_{4}\right]$ binary system. Interestingly, the thermal transition (solid red inverted triangle) measured in the present work at $37.5 \mathrm{~mol} \%$ $\left[\mathrm{C}_{3} \mathrm{mim}\right]\left[\mathrm{PF}_{6}\right]$ (and at $37.5 \mathrm{~mol} \%\left[\mathrm{C}_{3} \mathrm{mpyrr}\right]\left[\mathrm{PF}_{6}\right]$ ), and taken from the isoplethal section in Figure $6 \mathrm{~b}$, agrees very satisfactorily with the model; no metastable phase equilibria were observed at this particular composition. For the isoplethal section at a constant molar ratio $\left[\mathrm{C}_{3} \mathrm{mpyrr}\right]\left[\mathrm{PF}_{6}\right] /\left(\left[\mathrm{C}_{3} \mathrm{mpyrr}\right]\right.$ $\left[\mathrm{PF}_{6}\right]+\left[\mathrm{C}_{3} \mathrm{mpip}\right]\left[\mathrm{PF}_{6}\right]$ ) of 0.60 (Figure $6 \mathrm{~b}$ ), the binary and unary experimental data from Maximo et al. ${ }^{26}$ are also displayed at 0 and $100 \mathrm{~mol} \%\left[\mathrm{C}_{3} \mathrm{mim}\right]\left[\mathrm{PF}_{6}\right]$, respectively. In Figure $6 \mathrm{~b}$, agreement between the calculations and the DSC measurements is overall very satisfactory.

4.3.2. $\left[C_{3} m p y\right]\left[P F_{6}\right]-\left[C_{3}\right.$ mpip $]\left[P F_{6}\right]-\left[C_{3} m p y r r\right]\left[P F_{6}\right]$ System. The calculated liquidus projection of the $\left[\mathrm{C}_{3} \mathrm{mpy}\right]-$ $\left[\mathrm{PF}_{6}\right]-\left[\mathrm{C}_{3} \mathrm{mpip}\right]\left[\mathrm{PF}_{6}\right]-\left[\mathrm{C}_{3} \mathrm{mpyrr}\right]\left[\mathrm{PF}_{6}\right]$ system is displayed in Figure 7 . It is very similar to that of the $\left[\mathrm{C}_{3} \mathrm{mim}\right]\left[\mathrm{PF}_{6}\right]-$

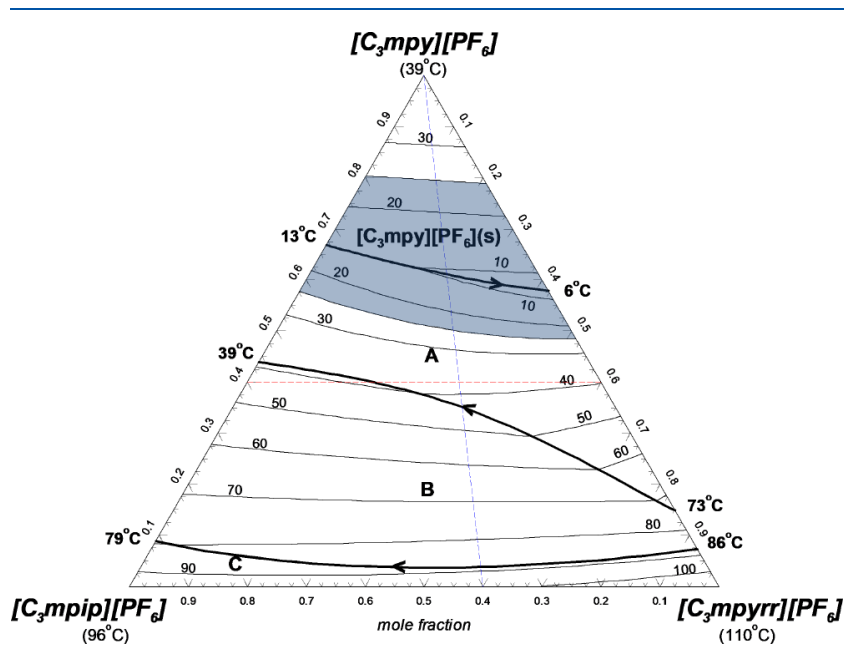

Figure 7. Calculated liquidus projection of the $\left[\mathrm{C}_{3} \mathrm{mpy}\right]\left[\mathrm{PF}_{6}\right]-$ $\left[\mathrm{C}_{3}\right.$ mpip $]\left[\mathrm{PF}_{6}\right]-\left[\mathrm{C}_{3} \mathrm{mpyrr}\right]\left[\mathrm{PF}_{6}\right]$ system. Notations: $\mathrm{A}=\left\{\left[\mathrm{C}_{3} \mathrm{mpip}\right]\right.$ $\left.\left[\mathrm{PF}_{6}\right]\left(s_{1}\right)-\left[\mathrm{C}_{3} \mathrm{mpyrr}\right]\left[\mathrm{PF}_{6}\right]\left(s_{1}\right)\right\}(\mathrm{ss}) ; \mathrm{B}=\left\{\left[\mathrm{C}_{3} \mathrm{mpip}\right]\left[\mathrm{PF}_{6}\right]\left(s_{2}\right)-\right.$ $\left.\left[\mathrm{C}_{3} \mathrm{mpyrr}\right]\left[\mathrm{PF}_{6}\right]\left(s_{2}\right)\right\}(\mathrm{ss}) ; \mathrm{C}=\left\{\left[\mathrm{C}_{3} \mathrm{mpip}\right]\left[\mathrm{PF}_{6}\right]\left(s_{3}\right)-\left[\mathrm{C}_{3} \mathrm{mpyrr}\right]-\right.$ $\left.\left[\mathrm{PF}_{6}\right]\left(s_{3}\right)\right\}(\mathrm{ss})$. The isoplethal sections at constant $40 \mathrm{~mol} \%$ $\left[\mathrm{C}_{3} \mathrm{mpy}\right]\left[\mathrm{PF}_{6}\right]$ (red dashed line) and at a constant molar ratio $\left[\mathrm{C}_{3} \mathrm{mpyrr}\right]\left[\mathrm{PF}_{6}\right] /\left(\left[\mathrm{C}_{3} \mathrm{mpyrr}\right]\left[\mathrm{PF}_{6}\right]+\left[\mathrm{C}_{3} \mathrm{mpip}\right]\left[\mathrm{PF}_{6}\right]\right)$ of 0.60 (blue dashed line) are shown schematically. The region of composition corresponding to room temperature ionic liquid (RTIL) mixtures is highlighted.

$\left[\mathrm{C}_{3} \mathrm{mpip}\right]\left[\mathrm{PF}_{6}\right]-\left[\mathrm{C}_{3} \mathrm{mpyrr}\right]\left[\mathrm{PF}_{6}\right]$ system (see Figure 5). This is not surprising since the two ternary systems only differ by the compounds $\left[\mathrm{C}_{3} \mathrm{mim}\right]\left[\mathrm{PF}_{6}\right]$ and $\left[\mathrm{C}_{3} \mathrm{mpy}\right]\left[\mathrm{PF}_{6}\right]$, which have the same melting temperature. Again, no ternary excess parameter was included for the liquid phase. The minimum liquidus temperature corresponds to the binary eutectic reaction liquid $=\left[\mathrm{C}_{3} \mathrm{mpy}\right]\left[\mathrm{PF}_{6}\right]+\left[\mathrm{C}_{3} \mathrm{mpyrr}\right]\left[\mathrm{PF}_{6}\right]\left(s_{1}\right)$ at 6 ${ }^{\circ} \mathrm{C}$. A few ternary mixtures in the isoplethal sections at constant $40 \mathrm{~mol} \%\left[\mathrm{C}_{3} \mathrm{mpy}\right]\left[\mathrm{PF}_{6}\right]$ (red dashed line in Figure $7)$ and at a constant molar ratio $\left[\mathrm{C}_{3} \mathrm{mpyrr}\right]\left[\mathrm{PF}_{6}\right] /\left(\left[\mathrm{C}_{3} \mathrm{mpyrr}\right]-\right.$ $\left.\left[\mathrm{PF}_{6}\right]+\left[\mathrm{C}_{3} \mathrm{mpip}\right]\left[\mathrm{PF}_{6}\right]\right)$ of 0.60 (blue dashed line in Figure 7 ) were investigated by DSC, and the calculations are shown along with the data in Figure 8a,b, respectively. In the former, the binary data from Maximo et al. ${ }^{26}$ at 0 and $60 \mathrm{~mol} \%$ $\left[\mathrm{C}_{3} \mathrm{mpyrr}\right]\left[\mathrm{PF}_{6}\right]$ are also displayed. In the latter, the binary and (a)

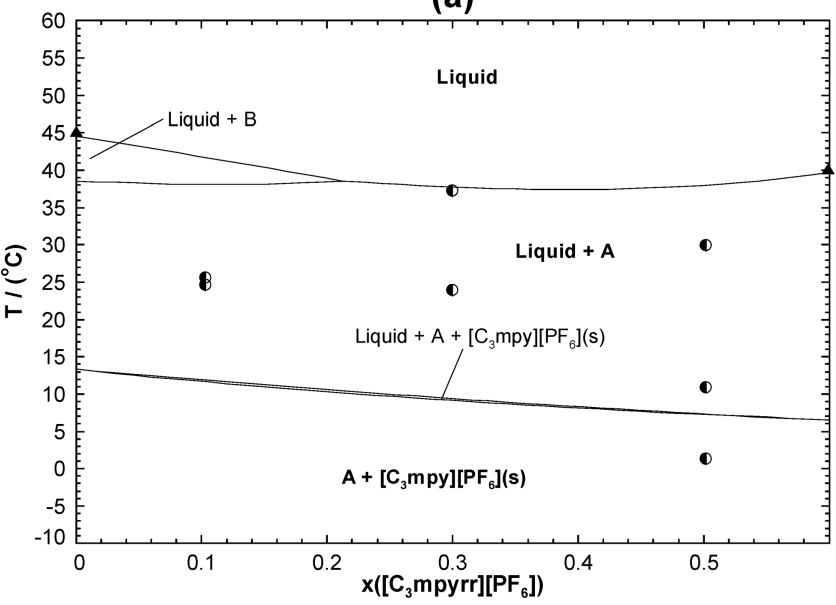

(b)

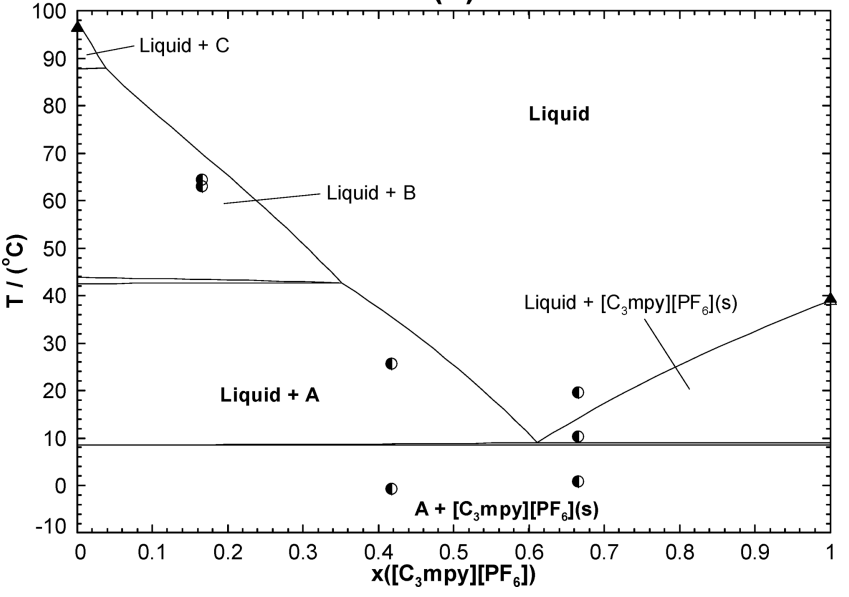

Figure 8. Calculated isoplethal sections in the $\left[\mathrm{C}_{3} \mathrm{mpy}\right]\left[\mathrm{PF}_{6}\right]-$ $\left[\mathrm{C}_{3} \mathrm{mpip}\right]\left[\mathrm{PF}_{6}\right]-\left[\mathrm{C}_{3} \mathrm{mpyrr}\right]\left[\mathrm{PF}_{6}\right]$ system along with measurements: (a) at $40 \mathrm{~mol} \%\left[\mathrm{C}_{3} \mathrm{mpy}\right]\left[\mathrm{PF}_{6}\right] ;$ (b) at a constant molar ratio $\left[\mathrm{C}_{3} \mathrm{mpyrr}\right]\left[\mathrm{PF}_{6}\right] /\left(\left[\mathrm{C}_{3} \mathrm{mpyrr}\right]\left[\mathrm{PF}_{6}\right]+\left[\mathrm{C}_{3} \mathrm{mpip}\right]\left[\mathrm{PF}_{6}\right]\right)$ of 0.60 . Experimental data are from the present work $(\mathbf{O})$ and Maximo et al. $^{26}(\boldsymbol{\Delta}, \triangle)$. Notations: $\mathrm{A}=\left\{\left[\mathrm{C}_{3} \mathrm{mpip}\right]\left[\mathrm{PF}_{6}\right]\left(s_{1}\right)-\left[\mathrm{C}_{3} \mathrm{mpyrr}\right]\left[\mathrm{PF}_{6}\right]\right.$ $\left.\left(s_{1}\right)\right\}(\mathrm{ss}) ; \mathrm{B}=\left\{\left[\mathrm{C}_{3} \mathrm{mpip}\right]\left[\mathrm{PF}_{6}\right]\left(s_{2}\right)-\left[\mathrm{C}_{3} \mathrm{mpyrr}\right]\left[\mathrm{PF}_{6}\right]\left(s_{2}\right)\right\}(\mathrm{ss}) ; \mathrm{C}=$ $\left\{\left[\mathrm{C}_{3} \mathrm{mpip}\right]\left[\mathrm{PF}_{6}\right]\left(s_{3}\right)-\left[\mathrm{C}_{3} \mathrm{mpyrr}\right]\left[\mathrm{PF}_{6}\right]\left(s_{3}\right)\right\}(\mathrm{ss})$.

unary data from Maximo et $\mathrm{al}^{26}$ are also shown at 0 and 100 mol \% $\left[\mathrm{C}_{3} \mathrm{mpy}\right]\left[\mathrm{PF}_{6}\right]$, respectively. In Figure 8a, some thermal transitions were observed in the intermediate temperature range and are not reproduced by the thermodynamic model; they are believed to correspond to metastable phase equilibria. In Figure $8 b$, agreement between the calculations and the DSC measurements is overall satisfactory.

4.3.3. $\left[C_{3} m p i p\right]\left[P F_{6}\right]-\left[C_{3} m p y\right]\left[P F_{6}\right]-\left[C_{3} m_{i m}\right]\left[P F_{6}\right]$ System. The calculated liquidus projection of the $\left[\mathrm{C}_{3} \mathrm{mpip}\right]\left[\mathrm{PF}_{6}\right]-$ $\left[\mathrm{C}_{3} \mathrm{mpy}\right]\left[\mathrm{PF}_{6}\right]-\left[\mathrm{C}_{3} \mathrm{mim}\right]\left[\mathrm{PF}_{6}\right]$ system is shown in Figure 9. Again, no ternary excess parameter was introduced for the liquid. The ternary eutectic reaction liquid $=\left[\mathrm{C}_{3} \mathrm{mpip}\right]\left[\mathrm{PF}_{6}\right]$ $\left(s_{1}\right)+\left[\mathrm{C}_{3} \mathrm{mpy}\right]\left[\mathrm{PF}_{6}\right]+\left[\mathrm{C}_{3} \mathrm{mim}\right]\left[\mathrm{PF}_{6}\right]$ is calculated at $-8{ }^{\circ} \mathrm{C}$ with a liquid composition of $\left(22.6 \mathrm{~mol} \%\left[\mathrm{C}_{3} \mathrm{mpip}\right]\left[\mathrm{PF}_{6}\right]+\right.$ $\left.41.5 \mathrm{~mol} \%\left[\mathrm{C}_{3} \mathrm{mpy}\right]\left[\mathrm{PF}_{6}\right]+35.9 \mathrm{~mol} \%\left[\mathrm{C}_{3} \mathrm{mim}\right]\left[\mathrm{PF}_{6}\right]\right)$. This corresponds to the minimum liquidus temperature in the ternary system. The isoplethal sections at constant $40 \mathrm{~mol} \%$ $\left[\mathrm{C}_{3} \mathrm{mpy}\right]\left[\mathrm{PF}_{6}\right]$ (red dashed line in Figure 9) and at a constant molar ratio $\left[\mathrm{C}_{3} \mathrm{mpy}\right]\left[\mathrm{PF}_{6}\right] /\left(\left[\mathrm{C}_{3} \mathrm{mpy}\right]\left[\mathrm{PF}_{6}\right]+\left[\mathrm{C}_{3} \mathrm{mim}\right]\left[\mathrm{PF}_{6}\right]\right)$ of 0.60 (blue dashed line in Figure 9) were measured by DSC, 


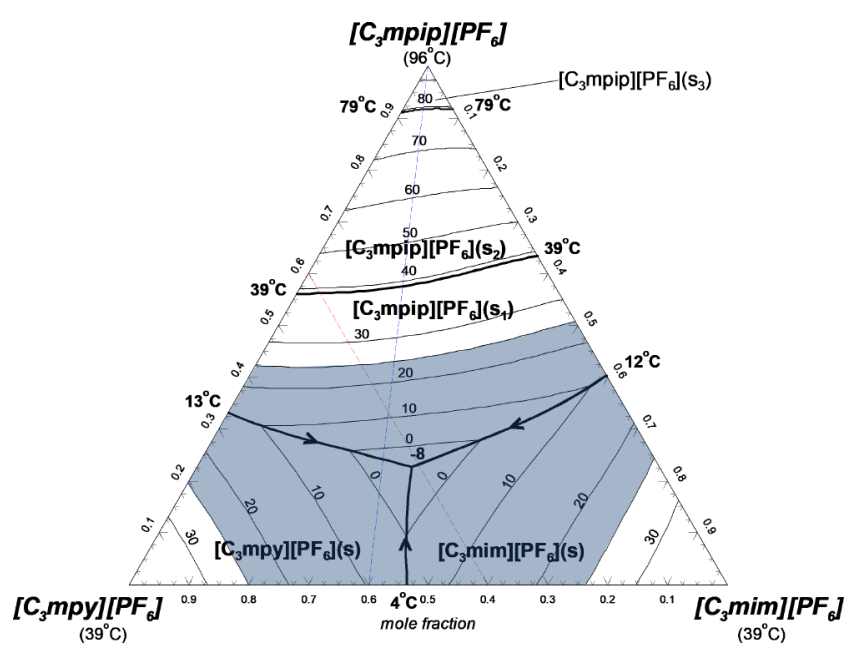

Figure 9. Calculated liquidus projection of the $\left[\mathrm{C}_{3} \mathrm{mpip}\right]\left[\mathrm{PF}_{6}\right]-$ $\left[\mathrm{C}_{3} \mathrm{mpy}\right]\left[\mathrm{PF}_{6}\right]-\left[\mathrm{C}_{3} \mathrm{mim}\right]\left[\mathrm{PF}_{6}\right]$ system. The isoplethal sections at constant $40 \mathrm{~mol} \%\left[\mathrm{C}_{3} \mathrm{mpy}\right]\left[\mathrm{PF}_{6}\right]$ (red dashed line) and at a constant molar ratio $\left[\mathrm{C}_{3} \mathrm{mpy}\right]\left[\mathrm{PF}_{6}\right] /\left(\left[\mathrm{C}_{3} \mathrm{mpy}\right]\left[\mathrm{PF}_{6}\right]+\left[\mathrm{C}_{3} \mathrm{mim}\right]\left[\mathrm{PF}_{6}\right]\right)$ of 0.60 (blue dashed line) are shown schematically. The region of composition corresponding to room temperature ionic liquid (RTIL) mixtures is highlighted.

and the calculations are compared to the measurements in Figure 10a,b, respectively. The filled circles in Figure 10a correspond to a ternary mixture, for which three consecutive heating/cooling cycles were used. For all other data points in Figure 10a,b, one cooling run was followed by one heating run. In Figure 10a, the binary data from Maximo et al. ${ }^{26}$ at 0 and 60 mol \% $\left[\mathrm{C}_{3} \mathrm{mpip}\right]\left[\mathrm{PF}_{6}\right]$ are also shown. Note that the thermal transitions measured at $\left.45.2 \mathrm{~mol} \%\left[\mathrm{C}_{3} \mathrm{mpy}_{[}\right] \mathrm{PF}_{6}\right]$ (and at 25.5 $\mathrm{mol} \%\left[\mathrm{C}_{3} \mathrm{mpip}\right]\left[\mathrm{PF}_{6}\right]$ ) and at $37.6 \mathrm{~mol} \%\left[\mathrm{C}_{3} \mathrm{mpy}\right]\left[\mathrm{PF}_{6}\right]$ (and at $37.9 \mathrm{~mol} \%\left[\mathrm{C}_{3} \mathrm{mpip}\right]\left[\mathrm{PF}_{6}\right]$ ) (see Figure $10 \mathrm{~b}$ ) are also displayed in Figure 10a. The corresponding calculated liquidus temperatures are virtually identical to those calculated at 40 mol \% $\left[\mathrm{C}_{3} \mathrm{mpy}\right]\left[\mathrm{PF}_{6}\right]$ and shown in Figure 10a. In the latter, at about $10 \mathrm{~mol} \%\left[\mathrm{C}_{3} \mathrm{mpip}\right]\left[\mathrm{PF}_{6}\right]$ only two thermal arrests were measured whereas three different thermal arrests are predicted by the thermodynamic model. As pointed out by Stolarska et al., ${ }^{29}$ owing to the dynamic nature of the DSC experimental technique, thermal transitions that should exist thermodynamically may be kinetically hindered. In Figure $10 \mathrm{~b}$, the binary and unary data from Maximo et al. ${ }^{26}$ are also shown at 0 and 100 $\mathrm{mol} \%\left[\mathrm{C}_{3} \mathrm{mpip}\right]\left[\mathrm{PF}_{6}\right]$, respectively. In Figure $10 \mathrm{a}, \mathrm{b}$, agreement between the calculations and the DSC measurements is usually very satisfactory.

4.3.4. $\left[C_{3} m p y r r\right]\left[P F_{6}\right]-\left[C_{3} m p y\right]\left[P F_{6}\right]-\left[C_{3} m_{i m}\right]\left[P F_{6}\right]$ System. The calculated liquidus projection of the $\left[\mathrm{C}_{3} \mathrm{mpyrr}\right]$ $\left[\mathrm{PF}_{6}\right]-\left[\mathrm{C}_{3} \mathrm{mpy}\right]\left[\mathrm{PF}_{6}\right]-\left[\mathrm{C}_{3} \mathrm{mim}\right]\left[\mathrm{PF}_{6}\right]$ system is shown in Figure 11 . It is very similar to that of the $\left[\mathrm{C}_{3} \mathrm{mpip}\right]\left[\mathrm{PF}_{6}\right]-$ $\left[\mathrm{C}_{3} \mathrm{mpy}\right]\left[\mathrm{PF}_{6}\right]-\left[\mathrm{C}_{3} \mathrm{mim}\right]\left[\mathrm{PF}_{6}\right]$ system (see Figure 9). This was expected since the two ternary systems only differ by the compounds $\left[\mathrm{C}_{3} \mathrm{mpyrr}\right]\left[\mathrm{PF}_{6}\right]$ and $\left[\mathrm{C}_{3} \mathrm{mpip}\right]\left[\mathrm{PF}_{6}\right]$, which have very similar cations and relatively close melting temperatures. As previously described, no ternary excess parameter was introduced for the liquid. The ternary eutectic reaction liquid $=$ $\left[\mathrm{C}_{3} \mathrm{mpyrr}\right]\left[\mathrm{PF}_{6}\right]\left(s_{1}\right)+\left[\mathrm{C}_{3} \mathrm{mpy}\right]\left[\mathrm{PF}_{6}\right]+\left[\mathrm{C}_{3} \mathrm{mim}\right]\left[\mathrm{PF}_{6}\right]$ is calculated at $-16{ }^{\circ} \mathrm{C}$ with a liquid composition of $(33.9 \mathrm{~mol}$ $\%\left[\mathrm{C}_{3} \mathrm{mpyrr}\right]\left[\mathrm{PF}_{6}\right]+33.9 \mathrm{~mol} \%\left[\mathrm{C}_{3} \mathrm{mpy}\right]\left[\mathrm{PF}_{6}\right]+32.2 \mathrm{~mol} \%$ $\left.\left[\mathrm{C}_{3} \mathrm{mim}\right]\left[\mathrm{PF}_{6}\right]\right)$. This is the minimum liquidus temperature in the ternary system. A few ternary mixtures in the isoplethal (a)

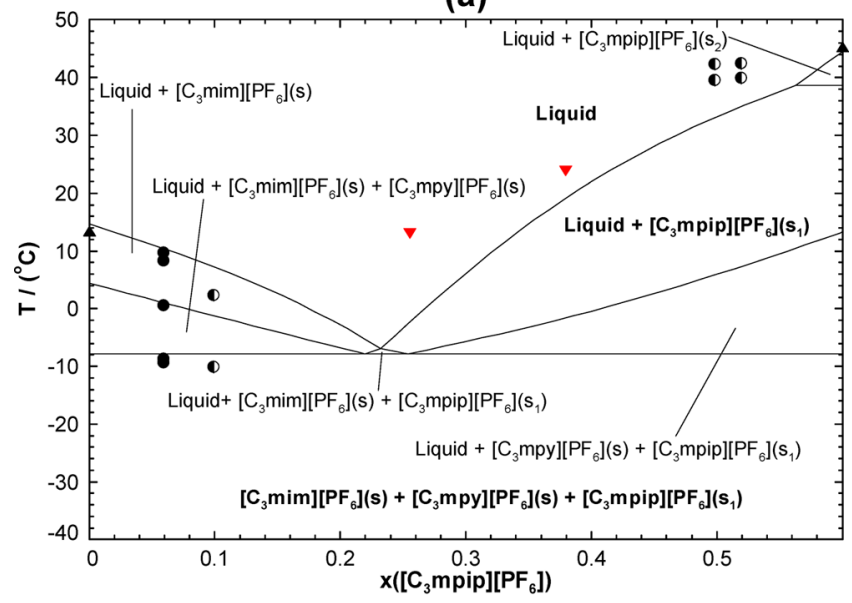

(b)

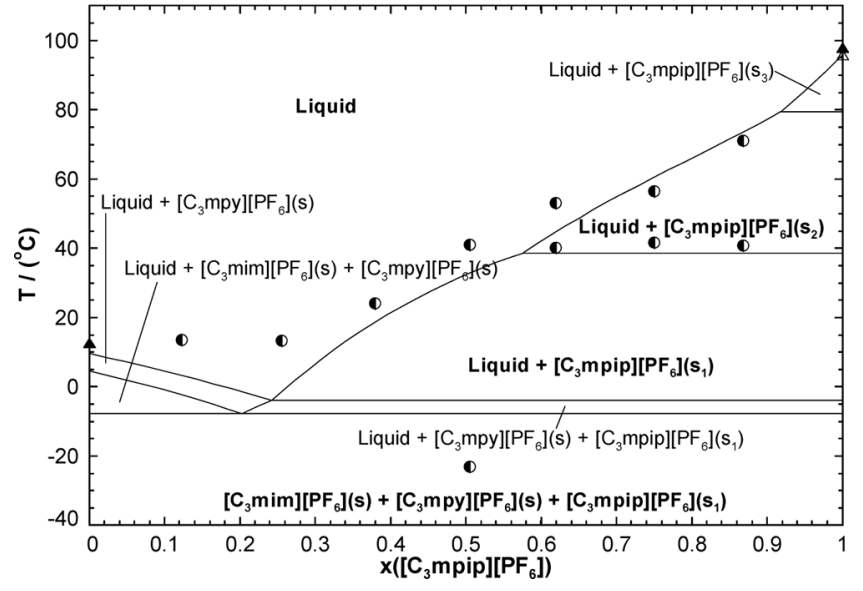

Figure 10. Calculated isoplethal sections in the $\left[\mathrm{C}_{3} \mathrm{mpip}\right]\left[\mathrm{PF}_{6}\right]-$ $\left[\mathrm{C}_{3} \mathrm{mpy}\right]\left[\mathrm{PF}_{6}\right]-\left[\mathrm{C}_{3} \mathrm{mim}\right]\left[\mathrm{PF}_{6}\right]$ system along with measurements. (a) At $40 \mathrm{~mol} \%\left[\mathrm{C}_{3} \mathrm{mpy}\right]\left[\mathrm{PF}_{6}\right]$. Experimental data are from the present work $(\boldsymbol{O}, \boldsymbol{\Theta})$ and Maximo et al. ${ }^{26}(\mathbf{\Delta})$. The thermal transitions (red $\boldsymbol{\nabla}$ ) measured at $45.2 \mathrm{~mol} \%\left[\mathrm{C}_{3} \mathrm{mpy}\right]\left[\mathrm{PF}_{6}\right]$ (and at $25.5 \mathrm{~mol} \%$ $\left[\mathrm{C}_{3} \mathrm{mpip}\right]\left[\mathrm{PF}_{6}\right]$ ) and at $\left.37.6 \mathrm{~mol} \%\left[\mathrm{C}_{3} \mathrm{mpy}_{[}\right] \mathrm{PF}_{6}\right]$ (and at $37.9 \mathrm{~mol}$ $\left.\%\left[\mathrm{C}_{3} \mathrm{mpip}\right]\left[\mathrm{PF}_{6}\right]\right)$, and taken from part $\mathrm{b}$, are also shown. (b) At a constant molar ratio $\left[\mathrm{C}_{3} \mathrm{mpy}\right]\left[\mathrm{PF}_{6}\right] /\left(\left[\mathrm{C}_{3} \mathrm{mpy}\right]\left[\mathrm{PF}_{6}\right]+\left[\mathrm{C}_{3} \mathrm{mim}\right]\right.$ $\left.\left[\mathrm{PF}_{6}\right]\right)$ of 0.60 . Experimental data are from the present work $(\mathrm{O})$ and Maximo et al. ${ }^{26}(\boldsymbol{\Delta}, \triangle)$.

sections at constant $40 \mathrm{~mol} \%\left[\mathrm{C}_{3} \mathrm{mpy}\right]\left[\mathrm{PF}_{6}\right]$ (red dashed line in Figure 11) and at a constant molar ratio $\left[\mathrm{C}_{3} \mathrm{mpy}\right]\left[\mathrm{PF}_{6}\right] /$ $\left(\left[\mathrm{C}_{3} \mathrm{mpy}\right]\left[\mathrm{PF}_{6}\right]+\left[\mathrm{C}_{3} \mathrm{mim}\right]\left[\mathrm{PF}_{6}\right]\right)$ of 0.60 (blue dashed line in Figure 11) were investigated by DSC, and the calculations are shown along with the data in Figure 12a,b, respectively. In the former, the binary data from Maximo et al. ${ }^{26}$ at 0 and $60 \mathrm{~mol} \%$ $\left[\mathrm{C}_{3} \mathrm{mpyrr}\right]\left[\mathrm{PF}_{6}\right]$ are also displayed. In the latter, the binary and unary data from Maximo et al. ${ }^{26}$ are also shown at 0 and 100 $\mathrm{mol} \%\left[\mathrm{C}_{3} \mathrm{mpyrr}\right]\left[\mathrm{PF}_{6}\right]$, respectively. Agreement between the calculations and the DSC measurements is overall satisfactory.

4.3.5. Quaternary System. Using the program FactOptimal, ${ }^{44}$ which is a coupling of the FactSage thermochemical software $^{45}$ with the powerful Mesh Adaptive Direct Search (MADS) algorithm, we identified the global minimum liquidus temperature in the quaternary system $\left[\mathrm{C}_{3} \mathrm{mim}\right]\left[\mathrm{PF}_{6}\right]-$ $\left[\mathrm{C}_{3}\right.$ mpyrr $]\left[\mathrm{PF}_{6}\right]-\left[\mathrm{C}_{3} \mathrm{mpy}\right]\left[\mathrm{PF}_{6}\right]-\left[\mathrm{C}_{3}\right.$ mpip $]\left[\mathrm{PF}_{6}\right]$. This global minimum is very close to the ternary eutectic in the $\left[\mathrm{C}_{3} \mathrm{mpyrr}\right]\left[\mathrm{PF}_{6}\right]-\left[\mathrm{C}_{3} \mathrm{mpy}\right]\left[\mathrm{PF}_{6}\right]-\left[\mathrm{C}_{3} \mathrm{mim}\right]\left[\mathrm{PF}_{6}\right]$ system (Fig- 


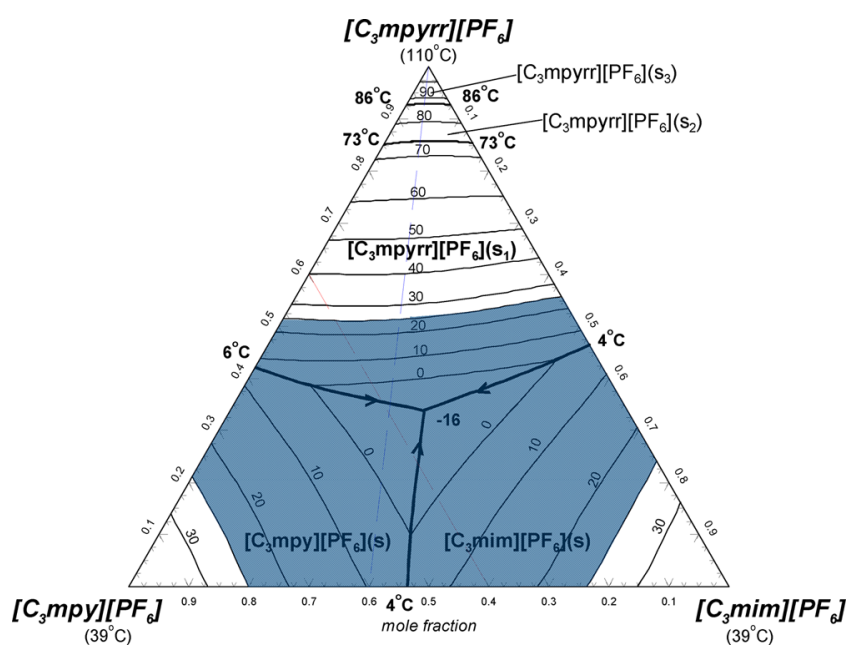

Figure 11. Calculated liquidus projection of the $\left[\mathrm{C}_{3} \mathrm{mpyrr}\right]\left[\mathrm{PF}_{6}\right]-$ $\left[\mathrm{C}_{3} \mathrm{mpy}\right]\left[\mathrm{PF}_{6}\right]-\left[\mathrm{C}_{3} \mathrm{mim}\right]\left[\mathrm{PF}_{6}\right]$ system. The isoplethal sections at constant $40 \mathrm{~mol} \%\left[\mathrm{C}_{3} \mathrm{mpy}\right]\left[\mathrm{PF}_{6}\right]$ (red dashed line) and at a constant molar ratio $\left[\mathrm{C}_{3} \mathrm{mpy}\right]\left[\mathrm{PF}_{6}\right] /\left(\left[\mathrm{C}_{3} \mathrm{mpy}\right]\left[\mathrm{PF}_{6}\right]+\left[\mathrm{C}_{3} \mathrm{mim}\right]\left[\mathrm{PF}_{6}\right]\right)$ of 0.60 (blue dashed line) are shown schematically. The region of composition corresponding to room temperature ionic liquid (RTIL) mixtures is highlighted.

ure 11). This is a true minimum, where three solid phases coexist $\left(\left[\mathrm{C}_{3} \mathrm{mpy}\right]\left[\mathrm{PF}_{6}\right], \quad\left[\mathrm{C}_{3} \mathrm{mim}\right]\left[\mathrm{PF}_{6}\right]\right.$, and a $\left[\mathrm{C}_{3} \mathrm{mpyrr}\right]$ $\left[\mathrm{PF}_{6}\right]\left(s_{1}\right)-\left[\mathrm{C}_{3} \mathrm{mpip}\right]\left[\mathrm{PF}_{6}\right]\left(s_{1}\right)$ solid solution which is almost pure $\left.\left[\mathrm{C}_{3} \mathrm{mpyrr}\right]\left[\mathrm{PF}_{6}\right]\left(s_{1}\right)\right)$, and the quaternary liquid contains virtually no $\left[\mathrm{C}_{3} \mathrm{mpip}\right]\left[\mathrm{PF}_{6}\right]$ (i.e., only about $0.003 \mathrm{~mol} \%$ ).

4.3.6. Discussion. For each ternary ionic liquid system investigated in the present work, the deviation from ideality can be quantified by the activity coefficients (relative to liquid standard state) of the three components. A temperature of 100 ${ }^{\circ} \mathrm{C}$ was selected since most ternary mixtures will then be liquid owing to the melting temperatures of the four pure $\left[\mathrm{PF}_{6}\right]$ based compounds (between 39 and $110{ }^{\circ} \mathrm{C}$ ). Let us consider the general case of a common-anion ternary liquid $\mathrm{A}\left[\mathrm{PF}_{6}\right]-$ $\mathrm{B}\left[\mathrm{PF}_{6}\right]-\mathrm{C}\left[\mathrm{PF}_{6}\right]$, where $\mathrm{A}, \mathrm{B}$, and $\mathrm{C}$ are the cations and $\left[\mathrm{PF}_{6}\right]^{-}$ is the common anion. The activity coefficient of $\mathrm{A}\left[\mathrm{PF}_{6}\right]$ in the ternary liquid can be defined as

$$
\left.\gamma_{\mathrm{A}\left[\mathrm{PF}_{6}\right]}=\frac{a_{\mathrm{A}\left[\mathrm{PF}_{6}\right]}}{\left(a_{\mathrm{A}\left[\mathrm{PF}_{6}\right]}\right)^{\text {ideal }}} \quad \text { (i.e., } \gamma_{\mathrm{A}\left[\mathrm{PF}_{6}\right]}=1 \text { in the ideal case }\right)
$$

$\left(a_{\mathrm{A}\left[\mathrm{PF}_{6}\right]}\right)^{\text {ideal }}$ is the activity of $A\left[\mathrm{PF}_{6}\right]$ in the ideal case, when the cations are randomly distributed on the cationic sublattice. Thus

$$
\begin{aligned}
& \left(a_{\mathrm{A}\left[\mathrm{PF}_{6}\right]}\right]^{\text {ideal }}=Y_{\mathrm{A}} Y_{\left[\mathrm{PF}_{6}\right]}=Y_{\mathrm{A}}=x_{\mathrm{A}}=\frac{n_{\mathrm{A}}}{n_{\mathrm{A}}+n_{\mathrm{B}}+n_{\mathrm{C}}}
\end{aligned}
$$

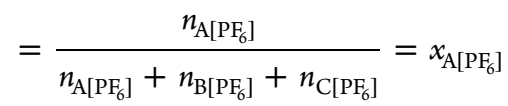

$\left(Y_{\left[\mathrm{PF}_{6}\right]}=1\right.$ since there is only one type of anion on the anionic sublattice.)

Finally, $\gamma_{\mathrm{A}\left[\mathrm{PF}_{6}\right]}=\frac{a_{\mathrm{A}\left[\mathrm{PF}_{6}\right]}}{x_{\mathrm{A}\left[\mathrm{PF}_{6}\right]}}$ (where $x_{\mathrm{A}\left[\mathrm{PF}_{6}\right]}$ is the mole fraction of $A\left[\mathrm{PF}_{6}\right]$ in the common-anion ternary liquid). There may be negative (i.e., $\gamma_{\mathrm{A}\left[\mathrm{PF}_{6}\right]}<1$ ) or positive (i.e., $\gamma_{\mathrm{A}\left[\mathrm{PF}_{6}\right]}>1$ ) deviations from ideality. The isoactivity lines (relative to liquid standard state) of the three components in the $\left\{\left[\mathrm{C}_{3} \mathrm{mim}\right]\right.$, (a)

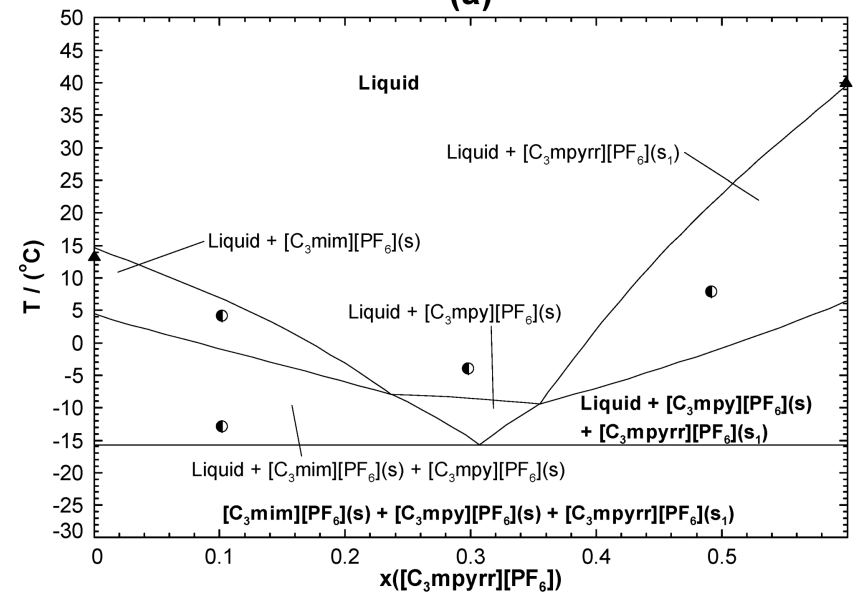

(b)

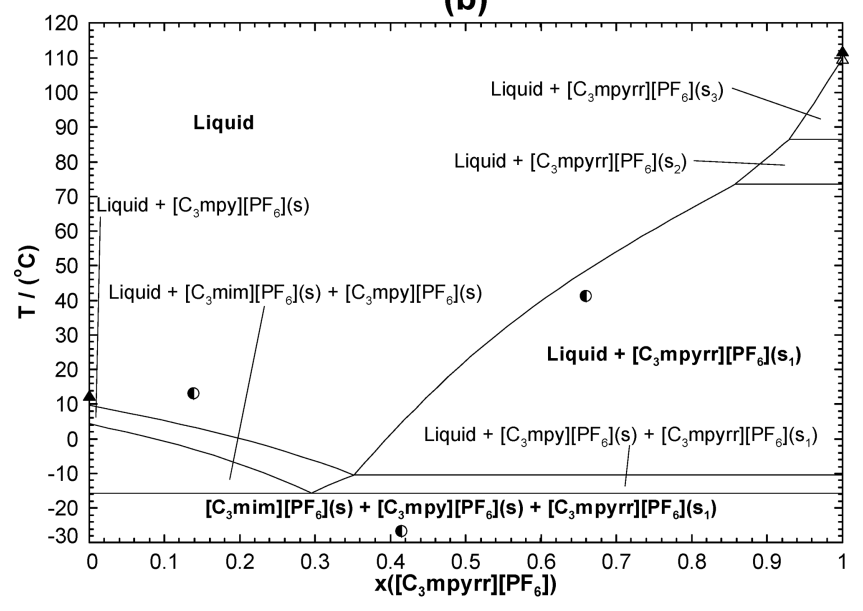

FIGURE 12

Figure 12. Calculated isoplethal sections in the $\left[\mathrm{C}_{3} \mathrm{mpyrr}\right]\left[\mathrm{PF}_{6}\right]-$ $\left[\mathrm{C}_{3} \mathrm{mpy}\right]\left[\mathrm{PF}_{6}\right]-\left[\mathrm{C}_{3} \mathrm{mim}\right]\left[\mathrm{PF}_{6}\right]$ system along with measurements: (a) at $40 \mathrm{~mol} \%\left[\mathrm{C}_{3} \mathrm{mpy}\right]\left[\mathrm{PF}_{6}\right] ;$ (b) at a constant molar ratio $\left[\mathrm{C}_{3} \mathrm{mpy}\right]\left[\mathrm{PF}_{6}\right] /\left(\left[\mathrm{C}_{3} \mathrm{mpy}\right]\left[\mathrm{PF}_{6}\right]+\left[\mathrm{C}_{3} \mathrm{mim}\right]\left[\mathrm{PF}_{6}\right]\right)$ of 0.60 . Experimental data are from the present work $(\mathbb{O})$ and Maximo et al. ${ }^{26}($ $\triangle)$.

[ $\mathrm{C}_{3}$ mpip $], \quad\left[\mathrm{C}_{3}\right.$ mpyrr $\left.]\right\}\left[\mathrm{PF}_{6}\right]$ common-anion ternary liquid calculated at $100{ }^{\circ} \mathrm{C}$ are shown in Figure 13. The ideal case is represented by the thin red lines, which correspond to a constant mole fraction of the investigated component. $\left[\mathrm{C}_{3} \mathrm{mim}\right]\left[\mathrm{PF}_{6}\right]$ displays negative deviations up to about 60 mol \%, and then positive deviations at higher content (Figure 13a). $\left[\mathrm{C}_{3} \mathrm{mpip}\right]\left[\mathrm{PF}_{6}\right]$ exhibits both positive and negative deviations up to about $50 \mathrm{~mol} \%$, and then only positive deviations at higher content (Figure $13 \mathrm{~b}$ ). Finally, [ $\mathrm{C}_{3} \mathrm{mpyrr}$ $\left[\mathrm{PF}_{6}\right]$ shows negative deviations up to about $40 \mathrm{~mol} \%$; at higher content, these decrease and are then replaced by positive deviations (Figure 13c). In the binary liquid $\left[\mathrm{C}_{3}\right.$ mpip $]\left[\mathrm{PF}_{6}\right]-\left[\mathrm{C}_{3}\right.$ mpyrr $]\left[\mathrm{PF}_{6}\right]$, both components have an ideal behavior since this liquid was assumed to be ideal at all compositions. The deviations from ideality are always small: Figure 14 shows the activity coefficients of all three components calculated at $100{ }^{\circ} \mathrm{C}$ along the isoplethal sections at constant $40 \mathrm{~mol} \%\left[\mathrm{C}_{3} \mathrm{mim}\right]\left[\mathrm{PF}_{6}\right]$ and at a constant molar ratio $\left[\mathrm{C}_{3} \mathrm{mpyrr}\right]\left[\mathrm{PF}_{6}\right] /\left(\left[\mathrm{C}_{3} \mathrm{mpyrr}\right]\left[\mathrm{PF}_{6}\right]+\left[\mathrm{C}_{3} \mathrm{mpip}\right]\left[\mathrm{PF}_{6}\right]\right)$ of 

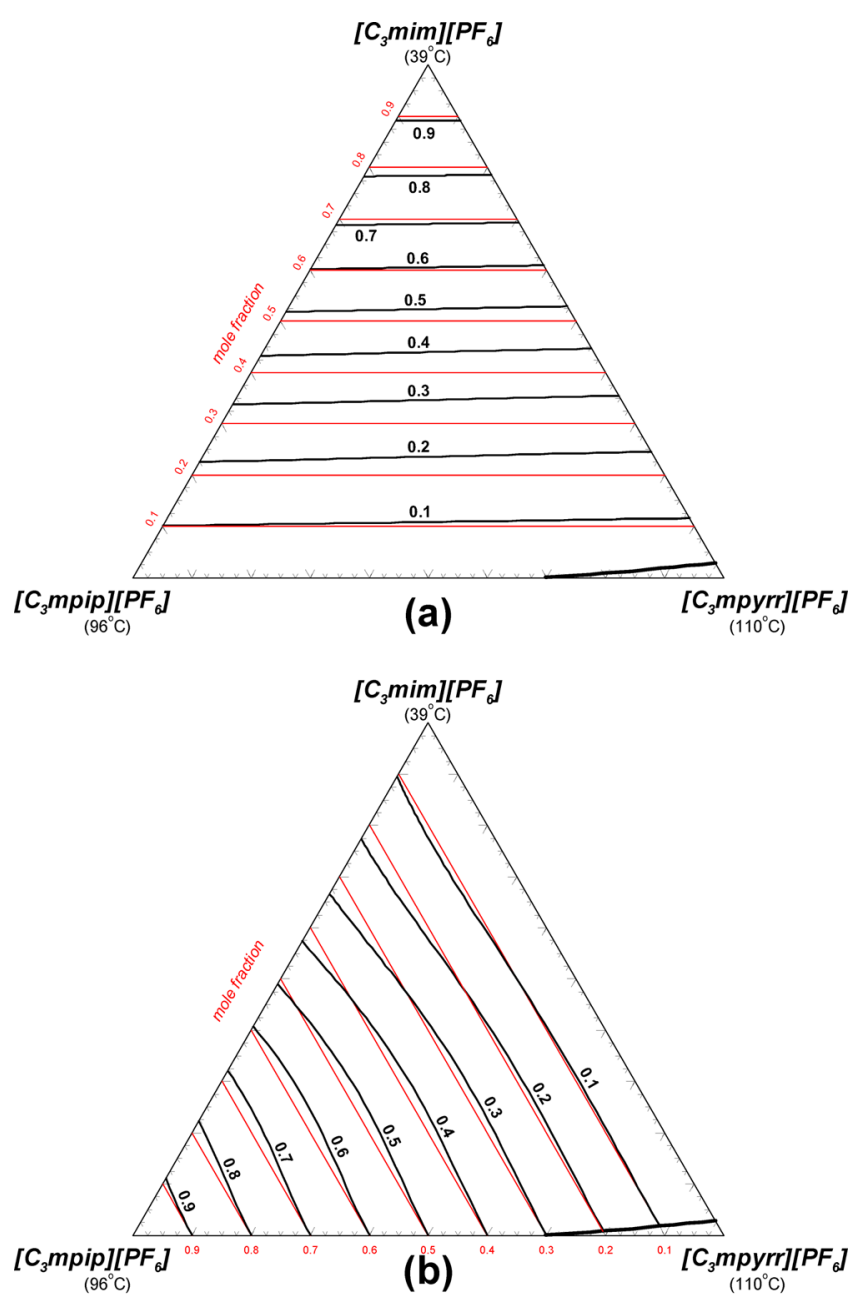

$\left.96^{\circ} \mathrm{C}\right)$

(b) $\left(110^{\circ} \mathrm{C}\right)$

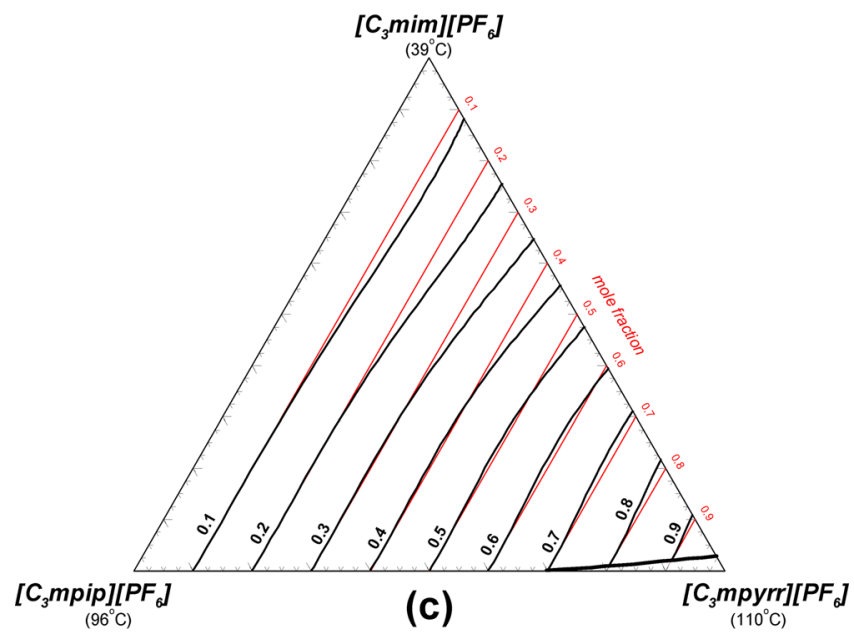

Figure 13. Calculated isoactivity lines (liquid standard state) at 100 ${ }^{\circ} \mathrm{C}$ in the $\left[\mathrm{C}_{3} \mathrm{mim}\right]\left[\mathrm{PF}_{6}\right]-\left[\mathrm{C}_{3} \mathrm{mpip}\right]\left[\mathrm{PF}_{6}\right]-\left[\mathrm{C}_{3} \mathrm{mpyrr}\right]\left[\mathrm{PF}_{6}\right]$ ternary liquid for (a) $\left[\mathrm{C}_{3} \mathrm{mim}\right]\left[\mathrm{PF}_{6}\right],(\mathrm{b})\left[\mathrm{C}_{3} \mathrm{mpip}\right]\left[\mathrm{PF}_{6}\right]$, and (c) [ $\left.\mathrm{C}_{3} \mathrm{mpyrr}\right]$ $\left[\mathrm{PF}_{6}\right]$. The ideal case is represented by the thin red lines, which correspond to a constant mole fraction of the investigated component.

0.60 , which were measured by DSC. The ranges of the calculated values are $0.85-1.05$ and $0.80-1.15$, respectively. As seen in Table 2, the optimized parameters for the $\left[\mathrm{C}_{3}\right.$ mpip]$\left[\mathrm{PF}_{6}\right]-\left[\mathrm{C}_{3} \mathrm{mim}\right]\left[\mathrm{PF}_{6}\right]$ and $\left[\mathrm{C}_{3} \mathrm{mpyrr}\right]\left[\mathrm{PF}_{6}\right]-\left[\mathrm{C}_{3} \mathrm{mim}\right]\left[\mathrm{PF}_{6}\right]$ binary liquids are very similar, but the constant parameter is more negative in the latter case. The $\left[\mathrm{C}_{3} \mathrm{mpip}\right]\left[\mathrm{PF}_{6}\right]-$
$\left[\mathrm{C}_{3} \mathrm{mpyrr}\right]\left[\mathrm{PF}_{6}\right]$ binary liquid was assumed to be ideal (eq 16) owing to the close similarity of the cations. Therefore, as a first approximation, one can consider that the various SNN cation-cation pairs are favored in the following decreasing order: $\left[\mathrm{C}_{3} \mathrm{mpyrr}\right]-\left[\mathrm{C}_{3} \mathrm{mim}\right]>\left[\mathrm{C}_{3} \mathrm{mpip}\right]-\left[\mathrm{C}_{3} \mathrm{mim}\right]>$ $\left[\mathrm{C}_{3}\right.$ mpip $]-\left[\mathrm{C}_{3}\right.$ mpyrr $]$. The $\left[\mathrm{C}_{3}\right.$ mpyrr $]-\left[\mathrm{C}_{3}\right.$ mim $]$ pairs are more favorable than the $\left[\mathrm{C}_{3} \mathrm{mpip}\right]-\left[\mathrm{C}_{3} \mathrm{mim}\right]$ pairs since the two rings have the same number of atoms. As seen in Figure 14 , the activity coefficients of $\left[\mathrm{C}_{3} \mathrm{mpip}\right]\left[\mathrm{PF}_{6}\right]$ and $\left[\mathrm{C}_{3} \mathrm{mpyrr}\right]$ $\left[\mathrm{PF}_{6}\right]$ have a very similar evolution as a function of composition in both isoplethal sections, which is due to the very similar cations. In the isoplethal section at constant 40 $\mathrm{mol} \%\left[\mathrm{C}_{3} \mathrm{mim}\right]\left[\mathrm{PF}_{6}\right]$ (Figure 14a), the activity coefficient of $\left[\mathrm{C}_{3} \mathrm{mim}\right]\left[\mathrm{PF}_{6}\right]$ continuously decreases as the $\left[\mathrm{C}_{3} \mathrm{mpyrr}\right]\left[\mathrm{PF}_{6}\right]$ content increases since the $\left[\mathrm{C}_{3} \mathrm{mpyrr}\right]-\left[\mathrm{C}_{3} \mathrm{mim}\right]$ pairs are more favorable than the $\left[\mathrm{C}_{3}\right.$ mpip $]-\left[\mathrm{C}_{3}\right.$ mim $]$ pairs. In the isoplethal section at a constant molar ratio $\left[\mathrm{C}_{3} \mathrm{mpyrr}\right]\left[\mathrm{PF}_{6}\right] /$ $\left(\left[\mathrm{C}_{3} \mathrm{mpyrr}\right]\left[\mathrm{PF}_{6}\right]+\left[\mathrm{C}_{3} \mathrm{mpip}\right]\left[\mathrm{PF}_{6}\right]\right)$ of 0.60 (Figure $14 \mathrm{~b}$ ), as the content of $\left[\mathrm{C}_{3} \mathrm{mim}\right]\left[\mathrm{PF}_{6}\right]$ increases, the activity coefficient of the latter remains lower than 1.0 over a large composition range (since the $\left[\mathrm{C}_{3} \mathrm{mim}\right]-\left[\mathrm{C}_{3} \mathrm{mpyrr}\right]$ and $\left[\mathrm{C}_{3} \mathrm{mim}\right]-$ $\left[\mathrm{C}_{3}\right.$ mpip $]$ pairs are more favorable than the $\left[\mathrm{C}_{3} \mathrm{mim}\right]-$ $\left[\mathrm{C}_{3} \mathrm{mim}\right]$ pairs) and then reaches 1.0 for pure $\left[\mathrm{C}_{3} \mathrm{mim}\right]\left[\mathrm{PF}_{6}\right]$. Simultaneously, the activity coefficients of $\left[\mathrm{C}_{3} \mathrm{mpip}\right]\left[\mathrm{PF}_{6}\right]$ and $\left[\mathrm{C}_{3} \mathrm{mpyrr}\right]\left[\mathrm{PF}_{6}\right]$ are close to 1.0 (i.e., ideality) and then become lower than 1.0 over a large composition range. This is due to the relative stability of the SNN cation-cation pairs mentioned above.

Similar calculations are presented in the Supporting Information for the three other ternary systems. Overall, small deviations from ideality are observed in the four ternary subsystems investigated. This is most likely due to the very similar cation structures of the $\left[\mathrm{C}_{3} \mathrm{mim}\right]\left[\mathrm{PF}_{6}\right],\left[\mathrm{C}_{3} \mathrm{mpy}\right]\left[\mathrm{PF}_{6}\right]$, $\left[\mathrm{C}_{3} \mathrm{mpyrr}\right]\left[\mathrm{PF}_{6}\right]$, and $\left[\mathrm{C}_{3} \mathrm{mpip}\right]\left[\mathrm{PF}_{6}\right]$ compounds.

\section{CONCLUSIONS}

The phase diagrams of the six binary subsystems and four ternary subsystems of the $\left\{\left[\mathrm{C}_{3} \mathrm{mim}\right],\left[\mathrm{C}_{3} \mathrm{mpy}\right],\left[\mathrm{C}_{3} \mathrm{mpyrr}\right]\right.$, $\left.\left[\mathrm{C}_{3} \mathrm{mpip}\right]\right\}\left[\mathrm{PF}_{6}\right]$ common-anion quaternary system were modeled. The Modified Quasichemical Model ${ }^{35,36}$ was used to model the liquid solution, while the Compound Energy Formalism ${ }^{37,38}$ was employed for the relevant solid solutions. The optimized parameters form a database for use with the FactSage thermochemical software ${ }^{45}$ and may be used, along with Gibbs energy minimization software, to calculate phase equilibria in the $\left\{\left[\mathrm{C}_{3} \mathrm{mim}\right],\left[\mathrm{C}_{3} \mathrm{mpy}\right],\left[\mathrm{C}_{3} \mathrm{mpyrr}\right],\left[\mathrm{C}_{3}\right.\right.$ mpip $\left.]\right\}$ $\left[\mathrm{PF}_{6}\right]$ quaternary system. The binary phase diagrams were modeled on the basis of the experimental data of Maximo et al. ${ }^{26}$ All binary subsystems display a simple eutectic behavior, except for the $\left[\mathrm{C}_{3} \mathrm{mpip}\right]\left[\mathrm{PF}_{6}\right]-\left[\mathrm{C}_{3} \mathrm{mpyrr}\right]\left[\mathrm{PF}_{6}\right]$ binary system which exhibits an extensive high-temperature $\left(s_{3}-s_{3}\right)$ solid solution over the entire composition range. Two different scenarios were considered in the present work: the first scenario assumed a negligible solid solubility between the lowtemperature allotropes $\left(s_{1}-s_{1}\right)$ and also between the intermediate-temperature allotropes $\left(s_{2}-s_{2}\right)$ of $\left[\mathrm{C}_{3} \mathrm{mpip}\right]\left[\mathrm{PF}_{6}\right]$ and $\left[\mathrm{C}_{3} \mathrm{mpyrr}\right]\left[\mathrm{PF}_{6}\right]$; the second scenario assumed a continuous solid solution between the low-temperature allotropes $\left(s_{1}-s_{1}\right)$ and also between the intermediate-temperature allotropes $\left(s_{2}-s_{2}\right)$. The second scenario was finally favored in order to best reproduce the experimental isoplethal sections at constant $40 \mathrm{~mol} \%\left[\mathrm{C}_{3} \mathrm{mim}\right]\left[\mathrm{PF}_{6}\right]$ and at a constant molar ratio $\left[\mathrm{C}_{3} \mathrm{mpyrr}\right]\left[\mathrm{PF}_{6}\right] /\left(\left[\mathrm{C}_{3} \mathrm{mpyrr}\right]\left[\mathrm{PF}_{6}\right]+\left[\mathrm{C}_{3} \mathrm{mpip}\right]-\right.$ 
(a)

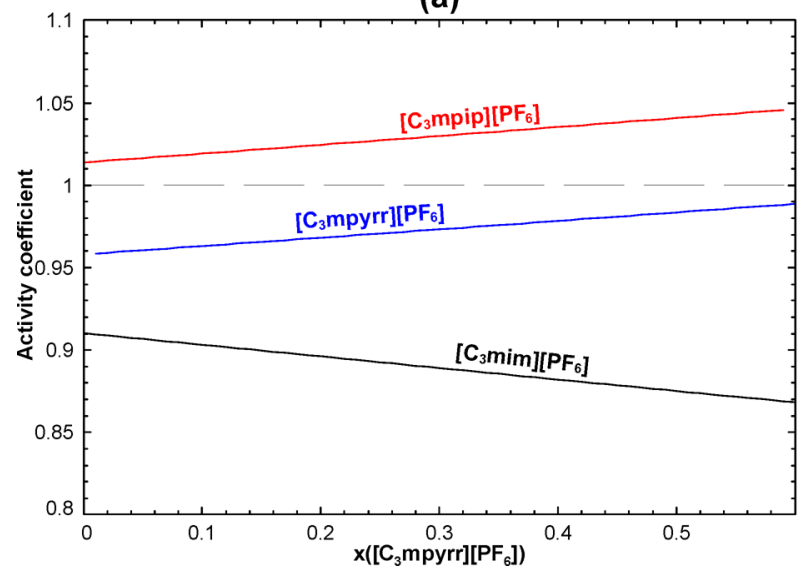

(b)

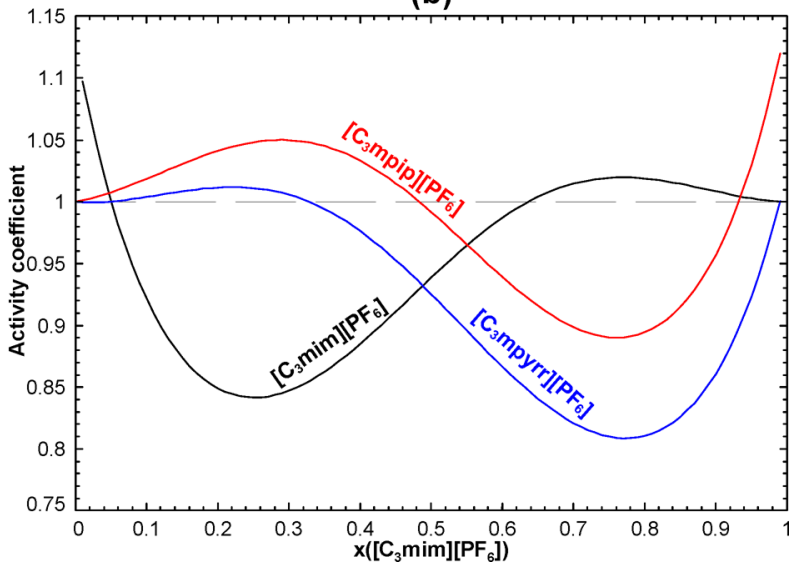

Figure 14. Calculated activity coefficients at $100{ }^{\circ} \mathrm{C}$ of the components (liquid standard state) in the $\left[\mathrm{C}_{3} \mathrm{mim}\right]\left[\mathrm{PF}_{6}\right]-\left[\mathrm{C}_{3} \mathrm{mpip}\right]\left[\mathrm{PF}_{6}\right]-$ $\left[\mathrm{C}_{3} \mathrm{mpyrr}\right]\left[\mathrm{PF}_{6}\right]$ ternary liquid along the isoplethal sections at (a) constant $40 \mathrm{~mol} \%\left[\mathrm{C}_{3} \mathrm{mim}\right]\left[\mathrm{PF}_{6}\right]$, and (b) a constant molar ratio $\left[\mathrm{C}_{3} \mathrm{mpyrr}\right]\left[\mathrm{PF}_{6}\right] /\left(\left[\mathrm{C}_{3} \mathrm{mpyrr}\right]\left[\mathrm{PF}_{6}\right]+\left[\mathrm{C}_{3} \mathrm{mpip}\right]\left[\mathrm{PF}_{6}\right]\right)$ of 0.60 .

$\left.\left[\mathrm{PF}_{6}\right]\right)$ of 0.60 in the $\left[\mathrm{C}_{3} \mathrm{mim}\right]\left[\mathrm{PF}_{6}\right]-\left[\mathrm{C}_{3} \mathrm{mpip}\right]\left[\mathrm{PF}_{6}\right]-$ $\left[\mathrm{C}_{3} \mathrm{mpyrr}\right]\left[\mathrm{PF}_{6}\right]$ ternary system, which were measured by DSC in the present work. The thermodynamic properties of the ternary liquid were calculated solely from the binary optimized parameters using an asymmetric interpolation method, with $\left[\mathrm{C}_{3} \mathrm{mim}\right]\left[\mathrm{PF}_{6}\right]$ as the asymmetric component. No ternary excess parameter was included for the liquid phase, and the excess Gibbs energies of the low-temperature $\left(s_{1}-s_{1}\right)$ and intermediate-temperature $\left(s_{2}-s_{2}\right)$ binary solid solutions were adjusted. The thermodynamic model does not reproduce the measured thermal transitions observed in the intermediatetemperature range in the isoplethal section at $40 \mathrm{~mol} \%$ $\left[\mathrm{C}_{3} \mathrm{mim}\right]\left[\mathrm{PF}_{6}\right]$, which are believed to correspond to metastable phase equilibria. Similarly, for the $\left[\mathrm{C}_{3} \mathrm{mpy}\right]\left[\mathrm{PF}_{6}\right]-\left[\mathrm{C}_{3} \mathrm{mpip}\right]-$ $\left[\mathrm{PF}_{6}\right]-\left[\mathrm{C}_{3} \mathrm{mpyrr}\right]\left[\mathrm{PF}_{6}\right]$ ternary system, an asymmetric interpolation method was used, with $\left[\mathrm{C}_{3} \mathrm{mpy}\right]\left[\mathrm{PF}_{6}\right]$ as the asymmetric component. Again, no ternary excess parameter was introduced in the liquid model. The DSC measurements for a few ternary mixtures in the isoplethal sections at constant $40 \mathrm{~mol} \%\left[\mathrm{C}_{3} \mathrm{mpy}\right]\left[\mathrm{PF}_{6}\right]$ and at a constant molar ratio $\left[\mathrm{C}_{3} \mathrm{mpyrr}\right]\left[\mathrm{PF}_{6}\right] /\left(\left[\mathrm{C}_{3} \mathrm{mpyrr}\right]\left[\mathrm{PF}_{6}\right]+\left[\mathrm{C}_{3} \mathrm{mpip}\right]\left[\mathrm{PF}_{6}\right]\right)$ of 0.60 were overall satisfactorily reproduced, apart from the metastable phase equilibria which are believed to have occurred in the intermediate-temperature range of the former section.

For the $\left[\mathrm{C}_{3} \mathrm{mpip}\right]\left[\mathrm{PF}_{6}\right]-\left[\mathrm{C}_{3} \mathrm{mpy}\right]\left[\mathrm{PF}_{6}\right]-\left[\mathrm{C}_{3} \mathrm{mim}\right]\left[\mathrm{PF}_{6}\right]$ ternary system, the newly measured isoplethal sections at constant $40 \mathrm{~mol} \%\left[\mathrm{C}_{3} \mathrm{mpy}\right]\left[\mathrm{PF}_{6}\right]$ and at a constant molar ratio $\left[\mathrm{C}_{3} \mathrm{mpy}\right]\left[\mathrm{PF}_{6}\right] /\left(\left[\mathrm{C}_{3} \mathrm{mpy}_{[}\right]\left[\mathrm{PF}_{6}\right]+\left[\mathrm{C}_{3} \mathrm{mim}\right]\left[\mathrm{PF}_{6}\right]\right)$ of 0.60 were usually very satisfactorily reproduced. A symmetric interpolation method was used, and no ternary excess parameter was required for the liquid. The calculated minimum liquidus temperature in the ternary system corresponds to a ternary eutectic at $-8{ }^{\circ} \mathrm{C}$. Similarly, for the $\left[\mathrm{C}_{3} \mathrm{mpyrr}\right]\left[\mathrm{PF}_{6}\right]-\left[\mathrm{C}_{3} \mathrm{mpy}\right]\left[\mathrm{PF}_{6}\right]-\left[\mathrm{C}_{3} \mathrm{mim}\right]\left[\mathrm{PF}_{6}\right]$ ternary system, a symmetric interpolation method was used, and no ternary excess parameter was introduced in the liquid model. The DSC measurements for a few ternary mixtures in the same isoplethal sections as for the previous ternary system were overall satisfactorily reproduced. A ternary eutectic reaction was calculated at $-16^{\circ} \mathrm{C}$. This is the global minimum liquidus temperature in the entire common-anion quaternary system.
Usually, DSC measurements are not easy to perform for ionic liquid systems owing to their large degree of supercooling and their tendency to form glasses. Agreement between the calculations from the developed thermodynamic model and the data obtained in the four ternary subsystems is considered to be overall satisfactory, apart from the observation of metastability in a few cases. It was possible to identify in each of the four ternary subsystems the region of composition where room temperature ionic liquid (RTIL) mixtures are formed.

All ternary ionic liquid systems studied in the present work display small deviations from ideality, owing to the similarities in the size and in the molecular structure of the cations.

This work is part of a larger project whose goal is to measure and model the phase diagrams and physical properties (such as viscosity) of ionic liquid mixtures (binary, ternary, and possibly higher-order).

\section{ASSOCIATED CONTENT}

\section{S Supporting Information}

The Supporting Information is available free of charge on the ACS Publications website at DOI: 10.1021/acs.jpcb.9b07545.

Composition variables (liquid model) relevant for the present work; experimental DSC data for the ternary ionic liquid mixtures; discussion of the first and second scenarios for the $\left[\mathrm{C}_{3} \mathrm{mim}\right]\left[\mathrm{PF}_{6}\right]-\left[\mathrm{C}_{3} \mathrm{mpip}\right]\left[\mathrm{PF}_{6}\right]-$ $\left[\mathrm{C}_{3} \mathrm{mpyrr}\right]\left[\mathrm{PF}_{6}\right]$ system; deviations from ideality in the $\left\{\left[\mathrm{C}_{3} \mathrm{mpy}\right], \quad\left[\mathrm{C}_{3} \mathrm{mpip}\right], \quad\left[\mathrm{C}_{3} \mathrm{mpyrr}\right]\right\}\left[\mathrm{PF}_{6}\right],\left\{\left[\mathrm{C}_{3} \mathrm{mpip}\right]\right.$, $\left.\left[\mathrm{C}_{3} \mathrm{mpy}\right],\left[\mathrm{C}_{3} \mathrm{mim}\right]\right\}\left[\mathrm{PF}_{6}\right]$, and $\left\{\left[\mathrm{C}_{3} \mathrm{mpyrr}\right],\left[\mathrm{C}_{3} \mathrm{mpy}\right]\right.$, $\left.\left[\mathrm{C}_{3} \mathrm{mim}\right]\right\}\left[\mathrm{PF}_{6}\right]$ ternary liquids (PDF)

\section{AUTHOR INFORMATION}

\section{Corresponding Author}

*E-mail: christian.robelin@polymtl.ca.

ORCID

Mónia A. R. Martins: 0000-0003-0748-1612

Simão P. Pinho: 0000-0002-9211-857X

João A. P. Coutinho: 0000-0002-3841-743X

Christian Robelin: 0000-0003-3081-6302

\section{Notes}

The authors declare no competing financial interest. 


\section{ACKNOWLEDGMENTS}

The modeling part of this project was supported by the Natural Sciences and Engineering Research Council of Canada (Discovery Grant RGPIN 435893-2013). The new DSC measurements in the four ternary subsystems were supported by the laboratories CICECO-Aveiro Institute of Materials, project POCI-01-0145-FEDER-007679 (ref FCT UID/CTM/ 50011/2019), and Associate Laboratory LSRE-LCM (ref FCT UID/EQU/50020/2019), both financed by national funds through the FCT/MEC and when appropriate cofinanced by FEDER under the PT2020 Partnership Agreement, and the project “AIProcMat@N2020-Advanced Industrial Processes and Materials for a Sustainable Northern Region of Portugal 2020" (ref NORTE-01-0145-FEDER-000006) supported by Norte Portugal Regional Operational Programme (NORTE 2020), under the Portugal 2020 Partnership Agreement, through the European Regional Development Fund (ERDF). Constructive discussions with Dr. Aïmen Gheribi, Prof. YounBae Kang, and Prof. Nick Virgilio were much appreciated.

\section{REFERENCES}

(1) Pas, S. J.; Dargusch, M. S.; MacFarlane, D. R. Crystallisation Kinetics of Some Archetypal Ionic Liquids: Isothermal and NonIsothermal Determination of the Avrami Exponent. Phys. Chem. Chem. Phys. 2011, 13, 12033-12040.

(2) Niedermeyer, H.; Hallett, J. P.; Villar-Garcia, I. J.; Hunt, P. A.; Welton, T. Mixtures of Ionic Liquids. Chem. Soc. Rev. 2012, 41, $7780-7802$.

(3) Raj, J. J.; Wilfred, C. D.; Shah, S. N.; Pranesh, M.; Mutalib, M. A.; Lethesh, K. C. Physicochemical and Thermodynamic Properties of Imidazolium Ionic Liquids with Nitrile and Ether Dual Functional Groups. J. Mol. Liq. 2017, 225, 281-289.

(4) Koel, M. Ionic Liquids in Chemical Analysis; CRC Press, 2008.

(5) Brennecke, J. F.; Maginn, E. J. Ionic Liquids: Innovative Fluids for Chemical Processing. AIChE J. 2001, 47, 2384-2389.

(6) Hardacre, C.; Parvulescu, V. Catalysis in Ionic Liquids: From Catalyst Synthesis to Application; Royal Society of Chemistry, 2014; Vol. 15.

(7) Martinelli, A.; Matic, A.; Johansson, P.; Jacobsson, P.; Börjesson, L.; Fernicola, A.; Panero, S.; Scrosati, B.; Ohno, H. Conformational Evolution of TFSI- in Protic and Aprotic Ionic Liquids. J. Raman Spectrosc. 2011, 42, 522-528.

(8) Fang, Z. Production of Biofuels and Chemicals with Ionic Liquids. Dissertation, Tohoku University, Japan, 2014.

(9) Suzuki, K.; Yamaguchi, M.; Kumagai, M.; Tanabe, N.; Yanagida, S. Dye-Sensitized Solar Cells with Ionic Gel Electrolytes Prepared from Imidazolium Salts and Agarose. C. R. Chim. 2006, 9, 611-616.

(10) Kendig, M. W.; DeNatale, J. F. Microfabricated Liquid Junction Reference Electrode. Patent US 8,211,283 B2: 2012 (USA).

(11) Lewandowski, A.; Galiński, M. Carbon-Ionic Liquid DoubleLayer Capacitors. J. Phys. Chem. Solids 2004, 65, 281-286.

(12) Siret, C.; Caratero, L.; Biensan, P. Lithium-Ion Battery Containing an Electrolyte Comprising an Ionic Liquid. Patent US 9,543,617 B2: 2017 (USA).

(13) Stark, A.; Seddon, K. R. Ionic Liquids. Kirk-Othmer Encyclopedia of Chemical Technology; Wiley, 2007.

(14) Plechkova, N. V.; Seddon, K. R. Applications of Ionic Liquids in the Chemical Industry. Chem. Soc. Rev. 2008, 37, 123-150.

(15) Gbassi, G. K.; Robelin, C. Thermodynamic Evaluation and Optimization of the $\mathrm{CH}_{3} \mathrm{COOLi}-\mathrm{CH}_{3} \mathrm{COOK}-\mathrm{CH}_{3} \mathrm{COOCs}$ System Using the Modified Quasichemical Model. Fluid Phase Equilib. 2015, 406, 134-141.

(16) Clough, M. T.; Crick, C. R.; Grasvik, J.; Hunt, P. A.; Niedermeyer, H.; Welton, T.; Whitaker, O. P. A Physicochemical Investigation of Ionic Liquid Mixtures. Chemical Science 2015, 6, $1101-1114$
(17) Mirarabrazi, M.; Stolarska, O.; Smiglak, M.; Robelin, C. SolidLiquid Equilibria for a Pyrrolidinium-Based Common-Cation Ternary Ionic Liquid System, and for a Pyridinium-Based Ternary Reciprocal Ionic Liquid System: An Experimental Study and a Thermodynamic Model. Phys. Chem. Chem. Phys. 2018, 20, 637-657.

(18) Dunstan, T. D. J.; Caja, J. Development of Low Melting Ionic Liquids Using Eutectic Mixtures of Imidazolium and Pyrazolium Ionic Liquids. ECS Trans. 2007, 3, 21-32.

(19) Annat, G.; Forsyth, M.; MacFarlane, D. R. Ionic Liquid Mixtures-Variations in Physical Properties and Their Origins in Molecular Structure. J. Phys. Chem. B 2012, 116, 8251-8258.

(20) Kick, M.; Keil, P.; König, A. Solid-Liquid Phase Diagram of the Two Ionic Liquids EmimCl and BmimCl. Fluid Phase Equilib. 2013, $338,172-178$.

(21) Stolarska, O.; Soto, A.; Rodríguez, H.; Smiglak, M. Properties Modification by Eutectic Formation in Mixtures of Ionic Liquids. RSC Adv. 2015, 5, 22178-22187.

(22) Ivanova, A. S.; Brinzer, T.; Roth, E. A.; Kusuma, V. A.; Watkins, J. D.; Zhou, X.; Luebke, D.; Hopkinson, D.; Washburn, N. R.; Garrett-Roe, S.; Nulwala, H. B. Eutectic Ionic Liquid Mixtures and Their Effect on $\mathrm{CO}_{2}$ Solubility and Conductivity. RSC Adv. 2015, 5, 51407-51412.

(23) Teles, A. R. R.; Correia, H.; Maximo, G. J.; Rebelo, L. P.; Freire, M. G.; Pereiro, A. B.; Coutinho, J. A. Solid-Liquid Equilibria of Binary Mixtures of Fluorinated Ionic Liquids. Phys. Chem. Chem. Phys. 2016, 18, 25741-25750.

(24) Scheuermeyer, M.; Kusche, M.; Agel, F.; Schreiber, P.; Maier, F.; Steinrueck, H.-P.; Davis, J. H.; Heym, F.; Jess, A.; Wasserscheid, P. Thermally Stable Bis(Trifluoromethylsulfonyl)Imide Salts and Their Mixtures. New J. Chem. 2016, 40, 7157-7161.

(25) Kunze, M.; Jeong, S.; Paillard, E.; Winter, M.; Passerini, S. Melting Behavior of Pyrrolidinium-Based Ionic Liquids and Their Binary Mixtures. J. Phys. Chem. C 2010, 114, 12364-12369.

(26) Maximo, G. J.; Santos, R. J. B. N.; Brandao, P.; Esperanca, J. M. S. S.; Costa, M. C.; Meirelles, A. J. A.; Freire, M. G.; Coutinho, J. A. P. Generating Ionic Liquids from Ionic Solids: An Investigation of the Melting Behavior of Binary Mixtures of Ionic Liquids. Cryst. Growth Des. 2014, 14, 4270-4277.

(27) Smiglak, M.; Bridges, N. J.; Dilip, M.; Rogers, R. D. Direct, Atom Efficient, and Halide-Free Syntheses of Azolium Azolate Energetic Ionic Liquids and Their Eutectic Mixtures, and Method for Determining Eutectic Composition. Chem. - Eur. J. 2008, 14, 11314-11319.

(28) Bayley, P. M.; Best, A. S.; MacFarlane, D. R.; Forsyth, M. Transport Properties and Phase Behaviour in Binary and Ternary Ionic Liquid Electrolyte Systems of Interest in Lithium Batteries. ChemPhysChem 2011, 12, 823-827.

(29) Stolarska, O.; Rodríguez, H.; Smiglak, M. Eutectic Mixtures of Pyrrolidinium-Based Ionic Liquids. Fluid Phase Equilib. 2016, 408, 19.

(30) Bharmoria, P.; Damarla, K.; Trivedi, T. J.; Malek, N. I.; Kumar, A. A Reciprocal Binary Mixture of Protic/Aprotic Ionic Liquids as a Deep Eutectic Solvent: Physicochemical Behavior and Application Towards Agarose Processing. RSC Adv. 2015, 5, 99245-99252.

(31) Hagiwara, R.; Tamaki, K.; Kubota, K.; Goto, T.; Nohira, T. Thermal Properties of Mixed Alkali Bis(Trifluoromethylsulfonyl) Amides. J. Chem. Eng. Data 2008, 53, 355-358.

(32) Kubota, K.; Nohira, T.; Takuya, G.; Hagiwara, R. Binary and Ternary Mixtures of MFSA ( $\mathrm{M}=\mathrm{Li}, \mathrm{K}, \mathrm{Cs})$ as New Inorganic Ionic Liquids. ECS Trans. 2009, 16, 91-98.

(33) Kubota, K.; Nohira, T.; Goto, T.; Hagiwara, R. Ternary Phase Diagrams of Alkali Bis(Trifluoromethylsulfonyl)Amides. J. Chem. Eng. Data 2008, 53, 2144-2147.

(34) Kubota, K.; Nohira, T.; Hagiwara, R. New Inorganic Ionic Liquids Possessing Low Melting Temperatures and Wide Electrochemical Windows: Ternary Mixtures of Alkali Bis(Fluorosulfonyl) Amides. Electrochim. Acta 2012, 66, 320-324. 
(35) Pelton, A.; Degterov, S.; Eriksson, G.; Robelin, C.; Dessureault, Y. The Modified Quasichemical Model I-Binary Solutions. Metall. Mater. Trans. B 2000, 31, 651-659.

(36) Pelton, A. D.; Chartrand, P. The Modified Quasi-Chemical Model: Part II. Multicomponent Solutions. Metall. Mater. Trans. A 2001, 32, 1355-1360.

(37) Sundman, B.; Ågren, J. A Regular Solution Model for Phases with Several Components and Sublattices, Suitable for Computer Applications. J. Phys. Chem. Solids 1981, 42, 297-301.

(38) Hillert, M. The Compound Energy Formalism. J. Alloys Compd. 2001, 320, 161-176.

(39) Kaufman, L.; Bernstein, H. Computer Calculation of Phase Diagrams. With Special Reference to Refractory Metals; Academic Press, 1970.

(40) Saunders, N.; Miodownik, A. P. Calphad (Calculation of Phase Diagrams): A Comprehensive Guide; Elsevier, 1998; Vol. 1.

(41) Kroupa, A. Modelling of Phase Diagrams and Thermodynamic Properties Using Calphad Method-Development of Thermodynamic Databases. Comput. Mater. Sci. 2013, 66, 3-13.

(42) Kohler, F. Estimation of the Thermodynamic Data for a Ternary System from the Corresponding Binary Systems. Monatsh. Chem. 1960, 91, 738-740.

(43) Toop, G. Predicting Ternary Activities Using Binary Data. Transactions of the Metallurgical Society of AIME 1965, 233, 850-854. (44) Gheribi, A. E.; Robelin, C.; Le Digabel, S.; Audet, C.; Pelton, A. D. Calculating All Local Minima on Liquidus Surfaces Using the FactSage Software and Databases and the Mesh Adaptive Direct Search Algorithm. J. Chem. Thermodyn. 2011, 43, 1323-1330.

(45) Bale, C. W.; Bélisle, E.; Chartrand, P.; Decterov, S. A.; Eriksson, G.; Gheribi, A. E.; Hack, K.; Jung, I.-H.; Kang, Y.-B.; Melançon, J.; et al. FactSage Thermochemical Software and Databases, 2010-2016. CALPHAD: Comput. Coupling Phase Diagrams Thermochem. 2016, 54, $35-53$.

(46) Chartrand, P.; Pelton, A. D. Thermodynamic Evaluation and Optimization of the LiCl-NaCl-KCl-RbCl-CsCl- $\mathrm{MgCl}_{2}-\mathrm{CaCl}_{2}$ System Using the Modified Quasi-Chemical Model. Metall. Mater. Trans. A 2001, 32, 1361-1383.

(47) Robelin, C.; Chartrand, P.; Pelton, A. D. Thermodynamic Evaluation and Optimization of the $\left(\mathrm{MgCl}_{2}+\mathrm{CaCl}_{2}+\mathrm{MnCl}_{2}+\mathrm{FeCl}_{2}\right.$ $+\mathrm{CoCl}_{2}+\mathrm{NiCl}_{2}$ ) System. J. Chem. Thermodyn. 2004, 36, 793-808. (48) Chartrand, P.; Pelton, A. D. Thermodynamic Evaluation and Optimization of the LiF-NaF-KF-MgF $-\mathrm{CaF}_{2}$ System Using the Modified Quasi-Chemical Model. Metall. Mater. Trans. A 2001, 32, $1385-1396$.

(49) Pelton, A. D.; Kang, Y.-B. Modeling Short-Range Ordering in Solutions. Int. J. Mater. Res. 2007, 98, 907-917.

(50) Robelin, C. Models for the Thermodynamic Properties of Molten Salt Systems: Perspectives for Ionic Liquids. Fluid Phase Equilib. 2016, 409, 482-494.

(51) Temkin, M. Mixtures of Fused Salts as Ionic Solutions. Acta Physicochim. URSS 1945, 20, 411-420.

(52) Ngo, H. L.; LeCompte, K.; Hargens, L.; McEwen, A. B. Thermal Properties of Imidazolium Ionic Liquids. Thermochim. Acta 2000, 357, 97-102.

(53) Golding, J.; Hamid, N.; MacFarlane, D.; Forsyth, M.; Forsyth, C.; Collins, C.; Huang, J. N-Methyl-N-Alkylpyrrolidinium Hexafluorophosphate Salts: Novel Molten Salts and Plastic Crystal Phases. Chem. Mater. 2001, 13, 558-564.

(54) Chartrand, P.; Pelton, A. D. Thermodynamic Evaluation and Optimization of the LiCl-NaCl-KCl-RbCl-CsCl-MgCl $2-\mathrm{CaCl}_{2}-\mathrm{SrCl}_{2}$ System Using the Modified Quasichemical Model. Can. Metall. Q. 2000, 39, 405-420.

(55) Chartrand, P.; Pelton, A. D. Thermodynamic Evaluation and Optimization of the LiCl-NaCl-KCl-RbCl-CsCl- $\mathrm{MgCl}_{2}-\mathrm{CaCl}_{2}-\mathrm{SrCl}_{2}-$ $\mathrm{BaCl}_{2}$ System Using the Modified Quasichemical Model. Can. Metall. Q. 2001, 40, 13-32.

(56) Robelin, C.; Chartrand, P.; Pelton, A. D. Thermodynamic Evaluation and Optimization of the $\left(\mathrm{NaCl}+\mathrm{KCl}+\mathrm{MgCl}_{2}+\mathrm{CaCl}_{2}+\right.$
$\mathrm{MnCl}_{2}+\mathrm{FeCl}_{2}+\mathrm{CoCl}_{2}+\mathrm{NiCl}_{2}$ ) System. J. Chem. Thermodyn. 2004, 36, 809-828.

(57) Robelin, C.; Chartrand, P. Thermodynamic Evaluation and Optimization of the $\left(\mathrm{NaCl}+\mathrm{KCl}+\mathrm{MgCl}_{2}+\mathrm{CaCl}_{2}+\mathrm{ZnCl}_{2}\right)$ System. J. Chem. Thermodyn. 2011, 43, 377-391.

(58) Renaud, E.; Robelin, C.; Heyrman, M.; Chartrand, P. Thermodynamic Evaluation and Optimization of the $(\mathrm{LiF}+\mathrm{NaF}+$ $\mathrm{KF}+\mathrm{MgF}_{2}+\mathrm{CaF}_{2}+\mathrm{SrF}_{2}$ ) System. J. Chem. Thermodyn. 2009, 41, $666-682$. 